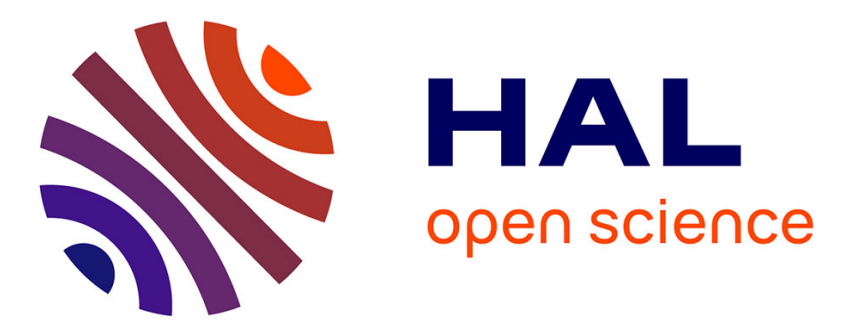

\title{
Contrasting sea-surface responses between the western Mediterranean Sea and eastern subtropical latitudes of the North Atlantic during abrupt climatic events of MIS 3
}

Aurélie Pénaud, Frédérique Eynaud, María-Fernanda Sánchez-Goñi, B. Malaize, Jean-Louis Turon, L. Rossignol

\section{To cite this version:}

Aurélie Pénaud, Frédérique Eynaud, María-Fernanda Sánchez-Goñi, B. Malaize, Jean-Louis Turon, et al.. Contrasting sea-surface responses between the western Mediterranean Sea and eastern subtropical latitudes of the North Atlantic during abrupt climatic events of MIS 3. Marine Micropaleontology, 2011, 80, pp.1-17. 10.1016/j.marmicro.2011.03.002 . insu-00588836

\section{HAL Id: insu-00588836 \\ https://hal-insu.archives-ouvertes.fr/insu-00588836}

Submitted on 26 Apr 2011

HAL is a multi-disciplinary open access archive for the deposit and dissemination of scientific research documents, whether they are published or not. The documents may come from teaching and research institutions in France or abroad, or from public or private research centers.
L'archive ouverte pluridisciplinaire HAL, est destinée au dépôt et à la diffusion de documents scientifiques de niveau recherche, publiés ou non, émanant des établissements d'enseignement et de recherche français ou étrangers, des laboratoires publics ou privés. 
1 Contrasting sea-surface responses between the western Mediterranean Sea and eastern subtropical latitudes of the North Atlantic during abrupt climatic events of MIS 3

13 *Corresponding author. Tel.: +33-298-498-741; fax: +33-298-498-760.

14 E-mail address: aurelie.penaud@univ-brest.fr. 


\section{ABSTRACT}

17 Dinoflagellate cyst (dinocyst) analysis was conducted on two cores from the SW Iberian margin and central Alboran Sea from which high quality records of Marine Isotope Stage 3 have been

19 previously derived. Our aim in this study is to compare the dinocyst signature between 50 and 25

$20 \mathrm{ka} \mathrm{BP}$ with existing datasets of foraminiferal and geochemical proxies related to hydrological

21 parameters. Quantitative reconstructions of sea-surface temperatures (SSTs) and salinities (SSS)

22 based on dinocysts are performed for the first time in this area. The results are compared to SSTs

23 derived from planktonic foraminifera and alkenone measurements, and to SSS calculated from

24 planktonic $\delta^{18} \mathrm{O}$ and foraminiferal SST. Significant oscillations related to Dansgaard-Oeschger

25 cycles are recorded in both cores. Dinocyst-derived hydrological parameters exhibit synchronous

26 fluctuations and similar values to those derived from the other methods, in particular when

27 considering quantitative reconstructions for February based on foraminifera and dinocysts. Our

28 study shows that the influence of subpolar waters was felt during each Greenland Stadial (GS) off

29 Portugal, and that the amplification of the Heinrich Stadial cooling in the Alboran Sea was

30 related to the penetration of subpolar waters through the Strait of Gibraltar. During Greenland

31 Interstadials (GI), we provide evidence for the occurrence of warm and nutrient-rich sea-surface

32 waters in the Alboran Sea, probably due to gyre-induced upwelling. Finally, the difference

33 between August and February dinocyst SST estimates suggests higher seasonal contrasts during

34 GS compared to GI at the two core sites. Additionally, precession appears to have an imprint on

35 dinocyst-derived long-term seasonality record. However, this observation needs to be confirmed

36 by longer records.

37 KEYWORDS: Dinocysts; SST and SSS quantification; Dansgaard-Oeschger; Greenland and 
41 The climate of the last glacial was characterised by a distinctive oscillatory mode, the so-called

\section{Introduction}

Dansgaard-Oeschger (D-O) cycles, originally described and defined in Greenland ice cores (Johnsen et al., 1992; Dansgaard et al., 1993; Grootes et al., 1993) and paced by an empirical 1470-year factor, the nature of which being presently not known (Schulz et al., 1999; Moreno et al., 2005; Voelker et al., 2006). Greenland Interstadials (GI) and Greenland Stadials (GS) including Heinrich Stadials (HS, following Sánchez-Goñi and Harrison, 2010), have previously been observed in marine climate records worldwide (e.g. Voelker et al., 2002; Hemming, 2004; Clement and Peterson, 2008). The impacts of HS, which primarily correspond to large ice-sheet collapses, are now fairly well characterised in the NE Atlantic and Mediterranean areas. Their occurrence is associated with enhanced aridity in the adjacent borderlands (Combourieu-Nebout et al., 2002; Sánchez-Goñi et al., 2002), increases in northward Saharan dust transport (Moreno et al., 2002; Bout-Roumazeilles et al., 2007) and sea-surface temperature coolings in the western Mediterranean Sea (e.g. Cacho et al., 1999) and on the Portuguese margin (e.g. Cayre et al., 1999; Pailler and Bard, 2002; de Abreu et al., 2003). However, the forcing mechanisms behind the initiation of HS and the inferred reorganisation of Meridional Overturning Circulation within the last glacial period are still a matter of debate (Kageyama et al., 2009). Furthermore, a full understanding of this rapid transmission of millennial-scale climatic variability from boreal to subtropical latitudes, involving both atmospheric and oceanic processes, remains elusive. It has been demonstrated that convection in the western Mediterranean, and thus export of Mediterranean Outflow Water (MOW), was strengthened during GS of the last $50 \mathrm{ka}$ (Cacho et al., 2000, 2006; Sierro et al., 2005; Voelker et al., 2006; Toucanne et al., 2007; Frigola et al., 2008). Consequently, it has been suggested that the Mediterranean could act as a major trigger for 
63 the Meridional Overturning Circulation to switch from stadial to interstadial mode through the

64 influence of MOW, providing saline water to the North Atlantic at times when the Meridional

65 Overturning Circulation was partially interrupted (Johnson, 1997; Bigg and Wadley, 2001;

66 Rogerson et al., 2006; Voelker et al., 2006). The production of MOW is mainly controlled by the

67 salinity budget of the Mediterranean Sea which depends on the climate characteristics over the

68 region and therefore on dominant modes of climatic variability, notably the North Atlantic

69 Oscillation (NAO). At present, the NAO pattern, oscillating at decadal and centennial scales, has

70 a strong influence on climate over a large part of Europe during winter, by affecting the storm

71 tracks and the associated relative moisture over the Mediterranean and northern Europe (e.g.

72 Hurrell, 1995; Serreze et al., 1997; Osborn et al., 1999). Over the eastern Atlantic subtropical

73 sector, it has been argued that this oscillation also has an imprint at centennial or millennial

74 timescales, and has been implicated in abrupt climatic events of the last glacial (Sánchez-Goñi et

75 al., 2002; Moreno et al., 2005; Bout-Roumazeilles et al. 2007; Daniau et al., 2007; Naughton et

76 al., 2009). Consequently, a change between two periods, each of them characterised by sustained

77 frequencies of a particular atmospheric configuration over several centuries, may have caused

78 significant variations of hydrological exchanges through time between the Atlantic and the

79 Mediterranean Sea (Moreno et al., 2005).

80 Previous high resolution palynological analysis of dinoflagellate cysts (dinocysts) and pollen on

81 core MD95-2042, collected off Portugal, indicate abrupt changes in sea surface and atmospheric

82 conditions, respectively, in response to D-O cycles (Eynaud, 1999; Sánchez-Goñi et al., 2000).

83 Additionally, a climatic contrast has been observed with respect to precipitation between the SW

84 Iberian margin and the Alboran region, with dryer conditions in southeastern Iberia than in its

85 southwestern part (Sánchez-Goñi et al., 2002). However, these studies do not quantify either

86 changes in SST and SSS, or discuss the possible impact of the observed precipitation gradient on 
87 the hydrological conditions of both sides of the Strait of Gibraltar between 25 and $50 \mathrm{ka} \mathrm{BP}$. To

88 fill this gap, we have analyzed dinocyst assemblages from core MD95-2043, located in the

89 Alboran Sea, and applied transfer functions. Furthermore, we have tested, for subtropical

90 latitudes, the robustness of quantitative paleotemperature and paleosalinity reconstructions

91 inferred from dinocysts against other proxy reconstructions (i.e. dinocyst- versus foraminifera-

92 versus alkenone- derived SST, and dinocyst- derived SSS versus SSS estimates calculated on the

93 basis of the $\delta^{18} \mathrm{O}$ of Globigerina bulloides associated with foraminiferal SST). 
2. Core locations and present-day environmental settings

Calypso cores MD95-2043 (368.6’ N; 2³7.3’ W; $1841 \mathrm{~m}$ water depth; $36 \mathrm{~m}$ long) and MD95$2042\left(37^{\circ} 48^{\prime} \mathrm{N} ; 10^{\circ} 10^{\prime} \mathrm{W} ; 3146 \mathrm{~m}\right.$ water depth; $39.56 \mathrm{~m}$ long) were retrieved from the central Alboran Sea and the SW Iberian margin, respectively (Fig. 1), and were both collected by the oceanographic R/V Marion Dufresne during the 1995 International Marine Global Change Studies I (IMAGES I) cruise (Bassinot and Labeyrie, 1996). The Mediterranean Sea is located between the path of the mid-latitude westerlies which dominate northern and central Europe, and the Azores High. At present, this basin experiences a typical seasonal cycle marked by cool-wet winters, and warm-dry summers. The resulting Mediterranean

104 water budget is marked by a strong freshwater deficit due to a net excess evaporation (Béthoux, 105 1979, 1984). During winter and spring, intense cold and dry continental air outbursts induce 106 strong evaporation and cooling in the northern Mediterranean Sea, and thus an increased density

107 of surface water masses. As a result, surface waters sink in several specific Mediterranean 108 regions, flow westward, and finally form the Mediterranean Outflow Water (MOW). The outflow 109 current is exported at depth towards the Atlantic Ocean, through the narrow Strait of Gibraltar 110 (main sill depth of $280 \mathrm{~m}$ ) and is split into two stability levels: an upper core centred between 500 $111 \mathrm{~m}$ and $800 \mathrm{~m}$, and a more saline and dense lower core found between 1000 and $1400 \mathrm{~m}$ (Ambar

112 et al., 2002). The MOW can be traced in the North Atlantic as a salinity and temperature

113 maximum at about $1 \mathrm{~km}$ depth (e.g. Hill and Mitchelson-Jacob, 1993; Iorga and Lorzier, 1999;

114 O’Neill-Baringer and Price, 1999), and mixes progressively with North Atlantic Intermediate

115 Waters (NAIW; Mauritzen, 1996). In the opposite direction, a North-Atlantic low-salinity surface 116 current penetrates the Alboran Sea and mixes with Levantine Intermediate Waters (which 117 resurface in the westernmost part of the Alboran Sea), forming the so-called Modified Atlantic 
118 Waters (MAW). The strong flow of MAW along the coast of Spain initiates the formation of two

119 anticyclonic gyres, the Western and Eastern Alboran Gyres (WAG and EAG; Fig. 1) whose

120 position and intensity fluctuate at a seasonal scale. The degree of development of the EAG, under

121 which core MD95-2043 is located (Fig. 1), controls the position and intensity of the permanent

122 Almeria-Oran Front (AOF; Fig. 1) (Tintoré et al., 1988; Rohling et al., 1995, 2009; Viúdez and

123 Tintoré, 1995). Upwelling cells occur along the AOF, this front marking the deflection of MAW

124 along the Algerian margin, forming the Algerian Current (AC; Fig. 1).

125 The main modern hydrological structures and currents of the western Iberian margin form part of

126 the North Atlantic Eastern Boundary Current (Fig. 1; Peliz et al., 2005; Relvas et al., 2007). They

127 are driven by the North Atlantic subtropical gyre intensity in relation to the seasonal

128 displacement of the Azores High (e.g. Fiúza, 1984; Fiúza et al., 1998). Core MD95-2042 is

129 located in the seasonal coastal upwelling band of the Portugal-Canary eastern boundary

130 upwelling system that is active mainly from April to October (Aristegui et al., 2005; Peliz et al.,

131 2005). The upwelling predominantly receives North Atlantic Central Waters (NACW) and, in

132 part, also MOW (Sánchez and Relvas, 2003). Occasionally, during winter months, a warm

133 northward-flowing surface current known as the Iberian Poleward Current or Portugal Coastal

134 Counter Current is formed by coastal convergence along the western Iberian margin. This

135 phenomenon occurs when weak northerlies are interspersed with strong south-southwesterly

136 winds (e.g. Fiúza et al., 1998; Peliz et al., 2005). This current can be traced as far as the Bay of

137 Biscay where it is known as the "Navidad Current". Winter warming in the southern Bay of

138 Biscay during Navidad years has been correlated with low values of the NAO index and this

139 current was found to extend from Portugal to Norway in exceptional Navidad years (Garcia-Soto

140 et al., 2002). 
141 Modern sea-surface conditions of the SW Iberian margin and Alboran Sea are characterised

142 respectively by mean annual salinities of 36.5 and $37.1 \mathrm{psu}$ (world dataset atlas compiled by

143 Schmidt, 1999 and Bigg and Rohling, 2000, http://data.giss.nasa.gov/o18data: Craig and Gordon

144 dataset for the Iberian margin and C. Pierre dataset for the Alboran Sea), February SSTs are

145 around 15.2 and $14.7^{\circ} \mathrm{C}$, respectively, and August SSTs are around 20 and $23.7^{\circ} \mathrm{C}$ (WOA 2001). 


\subsection{Chronostratigraphy}

150 Cores MD95-2043 (central Alboran Sea) and MD95-2042 (SW Iberian margin), characterised by

151 high sedimentation rates, are composed mainly of calcareous hemipelagic clays and have yielded

152 high resolution paleoceanographic records (e.g. Cacho et al., 1999 and Shackleton et al., 2000,

153 respectively).

154 The age model of core MD95-2042 is derived from 16 AMS ${ }^{14} \mathrm{C}$ dates and, for the period beyond

155 AMS ${ }^{14} \mathrm{C}$ range, by graphical tuning of the MD95-2042 planktonic $\delta^{18} \mathrm{O}$ record with Greenland 156 ice core $\delta^{18} \mathrm{O}$ records. The GISP 2 chronology (Bard et al., 2004) was used between 26 and $47 \mathrm{ka}$, 157 and the GRIPSS09sea chronology (Shackleton et al., 2004) was applied between 47 and 77 ka.

158 Further details of the age models are given in Daniau et al. (2007) and Sánchez-Goñi et al.

159 (2008).

160 The age model of core MD95-2043 is based on 21 AMS ${ }^{14} \mathrm{C}$ dates and graphical tuning of the

161 MD95-2043 alkenone SST record to GISP2 $\delta^{18} \mathrm{O}$ (Cacho et al., 1999). Due to the recent

162 improvement of the chronology of the SW Iberian margin core, some discrepancies in the two

163 age models appear in the dates of the climatic events at around $40 \mathrm{ka} \mathrm{BP}$. In these cases, we have

164 slightly modified the chronology of the Alboran Sea record for the time interval between 40 and $16550 \mathrm{ka}$, according to Sánchez-Goñi et al. (2009), in order to align the latter sedimentary sequence 166 with that of the SW Iberian margin.

\subsection{Dinoflagellate analysis}


170 Dinoflagellates are flagellate protists that occur in both marine and freshwater environments, and

171 which thrive in the depth range of 18-100 m in oceanic domains (Dodge and Harland, 1991;

172 Raine et al., 2002) and 0-10 $\mathrm{m}$ at the coastline. Water turbulence is greater in the neritic zone and

173 represents a limiting factor for light penetration and thus the maximum depth of dinoflagellate

174 habitats. Dinoflagellates reproduce primarily through fission, but sexual reproduction also occurs

175 resulting in a resting cyst which is preserved in sediments (Dodge et Harland, 1991; Head, 1996).

176 The distribution of dinoflagellate cysts (dinocysts) reflects physico-chemical parameters of the

177 overlying water masses (temperature, salinity, sea-ice cover, seasonality and nutrient availability)

178 (e.g. Turon, 1984; Mudie, 1992; Matthiessen, 1995; Rochon et al., 1999; Devillers and de Vernal,

179 2000; Zonneveld et al., 2001; Marret and Zonneveld, 2003; de Vernal and Marret, 2007).

180 Dinocyst analysis is therefore an essential tool for reconstructing Quaternary paleoenvironments

181 (e.g. Turon, 1984; Turon and Londeix, 1988; Eynaud et al., 2000, 2004, 2009; de Vernal et al.,

182 1997, 2001, 2005; Mudie et al., 2002, 2004; Grøsfjeld et al., 2006; Penaud et al., 2008, 2009, 183 2010).

185 Dinocyst assemblages were characterised at the species level on the sediment fraction smaller 186 than $150 \mu \mathrm{m}$ on 61 palynological slides for core MD95-2043 (this study) and on 71 slides for core MD95-2042 (Eynaud, 1999; Sánchez-Goñi et al., 2000). The preparation technique followed the protocol described by de Vernal et al. (1999) and Rochon et al. (1999), slightly modified at

189 the EPOC laboratory (Castera and Turon, http://www.epoc.u-

190 bordeaux.fr/index.php?lang=fr\&page=eq_paleo26). Each subsample of $8 \mathrm{~cm}^{3}$ was weighed, dried

191 overnight and then weighed again to obtain dry weight. Subsamples were then washed through a

$192150 \mu \mathrm{m}$ sieve and the fraction smaller than $150 \mu \mathrm{m}$ was used for palynological analysis. After

193 chemical and physical treatments (cold HCl, cold HF and sieving through single-use $10 \mu \mathrm{m}$ nylon 
mesh screens), the final residue was mounted between slide and coverslip with glycerine jelly

195 coloured with fuschin. Identifications and counts were performed using a Leica DM 6000

196 microscope at $400 \times$ magnification, and counts aimed to reach 300 specimens wherever possible

197 for each sample (cf. Appendix A). Taxonomic identifications are consistent with those of

198 Fensome et al. (1998) and Fensome and Williams (2004). Brigantedinium cysts are grouped

199 together and include all spherical brown cysts, since it is rarely possible to identify them at the

200 species level due to their crumbled aspect which masks the archeopyle.

201 Dinocyst assemblages were described by the percentages of each species calculated on the basis

202 of the total dinocyst sum including the few unidentified taxa and excluding pre-Quaternary cysts.

203 Palynomorph concentrations were calculated using the marker grain method (de Vernal et al.,

204 1999). Aliquot volumes of Lycopodium spores were added to each sample before chemical

205 treatments in order to obtain palynomorph concentrations.

\section{3.3. Quantitative reconstructions of sea-surface parameters}

\subsubsection{Dinocyst SST and SSS reconstructions}

211 We used a transfer function based on the Modern Analogue Technique (MAT) to reconstruct sea-

212 surface hydrological parameters from dinocysts. The MAT principally uses the statistical distance

213 between fossil (paleoceanographic record) and current (modern database) assemblages. The

214 calculation of past hydrological parameters relies on a weighted average of the SST values of the

215 best modern analogues found (minimum and maximum number of analogues imposed in the

216 transfer functions are 5; cf. Appendix B for the list of analogues found for each sample). The 
217 maximum weight is given for the closest analogue in terms of statistical distance. The reader is

218 referred to Guiot and de Vernal (2007) for a review of theory of transfer functions and to de

219 Vernal et al. $(2001,2005)$ for a step by step description of the application of transfer functions to

220 dinocysts, including discussion about the degree of accuracy of the method.

222 The dinocyst transfer function used in this work (cf. de Vernal et al., 2005; GEOTOP website:

223 http://www.unites.uqam.ca/geotop/monographie_n940/eng/index.shtml) is derived from a

224 modern database comprising 60 dinocyst species and 940 stations from the North Atlantic, Arctic

225 and North Pacific oceans and their adjacent seas, including the Mediterranean Sea (84 stations

226 including station "M1039", cf. Fig. 1; Mangin, 2002), as well as epicontinental environments

227 such as the Estuary and Gulf of St. Lawrence, the Bering Sea and the Hudson Bay. The transfer

228 function ( $\mathrm{n}=940)$ is run under the "3Pbase" software (Guiot and Goeury, 1996). This software

229 was originally developed for pollen-based quantitative climate reconstruction (http://www.imep-

230 cnrs.com/pages/3pbase.htm) and was subsequently applied to dinocyst assemblages (e.g. de

231 Vernal et al., 2001, 2005). An index "Dmin", provided by the software "3PBase", allows testing

232 the reliability of the reconstructions (cf. de Vernal et al., 2005). This index describes, for each

233 sample analyzed, the distance between the closest analogue found by the transfer function and the

234 fossil assemblage. A threshold value is calculated from the calibration of the database for the

235 identification of non-similar or very bad analogues. This threshold value provided by the

236 software "3PBase" is 71.72 and, below this value, the similarity between the modern data and the

237 fossil record is considered significant (cf. Appendix B for the Dmin values calculated for each

238 sample). The authors caution that the full reference set has been used for the calculations of

239 hydrological parameters without any regional selection of samples within the modern database. In

240 this study, we present February and August mean sea-surface temperatures (SST, with prediction 
241 errors of $\pm 1.2^{\circ} \mathrm{C}$ and $\pm 1.8^{\circ} \mathrm{C}$ respectively), and February and August mean sea-surface salinities 242 (SSS, with prediction errors of \pm 1.7 for both).

\subsubsection{Foraminiferal SST and SSS reconstructions}

246 In the same way, we used a transfer function based on the MAT to reconstruct foraminiferal SST

247 from the foraminiferal assemblages of cores MD95-2042 (Cayre et al., 1999) and MD95-2043

248 (Pérez-Folgado et al., 2003). Calculation of past hydrological parameters relies on a weighted

249 average of the SST values of the best 5 modern analogues found systematically. This transfer

250 function has been developed at EPOC laboratory ("Environnements et Paléoenvironnements

251 OCéaniques", Bordeaux1 University, France). The MAT (e.g. Kucera, 2007) is run under the "R"

252 software using a script first developed for dinocyst transfer functions

253 (http://www.cerege.fr/IMG/pdf/ECCOR_StatRAvr08.pdf). The modern database relies on a

254 modern database of 1007 modern assemblages and is derived from the ones developed separately

255 for the North Atlantic and the Mediterranean seas during the MARGO project (Kucera et al.,

256 2005; Hayes et al., 2005). These databases were merged together to offer a larger set of analogues

257 for subtropical reconstructions over the last glacial period notably (Eynaud et al., 2009;

258 Matsuzaki et al., in press). Modern hydrological parameters were requested from the WOA 2008

259 database using the tool developed during the MARGO project (http://www.geo.uni-

260 bremen.de/geomod/staff/csn/woasample.html). This method allows the reconstruction of annual

261 and seasonal (winter, spring, summer and fall) SST. In this paper, we present winter and summer

262 mean SST with a prediction error of $\pm 1.2^{\circ} \mathrm{C}$ and $\pm 1.3^{\circ} \mathrm{C}$ respectively, and annual SST with a

263 prediction error of $\pm 1.1^{\circ} \mathrm{C}$ (Eynaud et al, 2009; Matsuzaki et al., in press). 
265 SSS estimates have been derived using the approach summarised in Malaizé and Caley (2009) for 266 calibration of the salinity-water isotope relationship. Craig and Gordon (1965) established the 267 first salinity-water isotope relationship as follows:

$$
\delta^{18} \mathrm{Osw}=0.66 \mathrm{SSS}-23.5
$$

269 Since this pioneer work, many measurements have been performed and many different 270 relationships, with different slopes, have been derived for different oceans (Ostlund et al., 1987, 271 Schmidt, 1999; LeGrande and Schmidt, 2006). Discrepancies in slope and in intercept values are 272 due to local characteristics, on spatial and temporal scales. For the Atlantic Ocean, an important 273 dataset, established from several decades of oceanographic measurements, allows revision of the 274 Craig and Gordon (1965) calibration and the determination of a new relationship, with a mean 275 slope component of 0.558 .

276 In order to estimate past changes in oceanic $\delta^{18}$ Osw, Epstein et al. (1953) established a 277 paleotemperature equation which links temperature with the isotopic composition of calcite $278\left(\delta^{18} \mathrm{Oc}\right)$ in calcareous shells (e.g. foraminifera) and the ambient waters $\left(\delta^{18} \mathrm{Osw}\right)$. Shackleton and 279 Opdyke (1973) have adapted the equation of Epstein et al. (1953) as follows:

$$
\mathrm{T}=16.9-4.38\left(\delta^{18} \mathrm{Oc}-\delta^{18} \mathrm{Osw}\right)+0.13\left(\delta^{18} \mathrm{Oc}-\delta^{18} \mathrm{Osw}\right)^{2}
$$

281 Stable isotope $\delta^{18}$ Oc measurements in cores MD95-2042 (Cayre et al., 1999; Shackleton et al., 282 2000) and MD95-2043 (Cacho et al., 1999) were carried out on G. bulloides monospecific 283 samples. Following the pioneer study of Duplessy et al. (1991), we corrected the summer 284 temperature by $1^{\circ} \mathrm{C}$ for G. bulloides species. By solving the Shackleton and Opdyke (1973) 285 equation, we obtain $\delta^{18}$ Osw variations, which integrate the signal of both local and global 286 variations. To remove the global influence of continental ice volume, we used estimations of past 287 global $\delta^{18}$ Osw changes based on benthic isotopic records and coral terrace growth (Waelbroeck et 
288 al., 2002), and used the modern $\delta^{18}$ Osw values (1.2\%o for the Alboran Sea and $0.97 \%$ for the 289 Iberian margin) extracted from the world dataset atlas compiled by Schmidt (1999) and Bigg and 290 Rohling (2000) (C. Pierre dataset for the Alboran Sea, and Craig and Gordon dataset for the 291 Iberian margin, from http://data.giss.nasa.gov/o18data). The residual $\delta^{18}$ Osw "ice-corrected" 292 signal is then converted into quantitative SSS values for both cores, using a mean slope of 0.558. 293 SSS uncertainties of around 1 psu derive from the prediction error of the foraminiferal SST 294 reconstructions $\left(1.8^{\circ} \mathrm{C}\right.$ uncertainty linked with August SST reconstructions corresponds to a 0.45 $295 \%$ uncertainty on a $\delta$ scale), as well as on uncertainties in the global $\delta^{18}$ Osw changes linked to 296 sea level changes $(0.15 \%)$. 


\section{Dinocyst assemblages through time}

299 Concerning the species of the genus Brigantedinium spp., round brown cysts formed by

300 heterotrophic dinoflagellates, it is important to take into account the fact that high occurrences of

301 Brigantedinium spp. can be linked to better preservation under hypoxic or anoxic bottom

302 conditions (Combourieu-Nebout et al., 1998; Zonneveld et al., 2001; Kodrans-Nsiah et al., 2008).

303 We can not exclude that Brigantedinium spp. may have been subjected to dissolution since deep

304 ventilation in the western Mediterranean Sea (and thus oxidation processes) during GS was

305 stronger than during GI of the last glacial (cf. benthic $\delta^{13} \mathrm{C}$ in Fig. 4; Cacho et al., 2006).

306 However, Brigantedinium spp. are present throughout the Alboran core without any clear trend

307 between few percentages during GS and high percentages during GI. We can thus expect to

308 reconstruct dinocyst assemblages without significant preservational problems.

309 When comparing both cores (Fig. 2), we note extremely high relative abundances of

310 Brigantedinium spp. (30-89\%) on the SW Iberian margin (Fig. 2b). This may reflect the high

311 productivity induced by permanent or intensified upwelling cells along the Portuguese margin

312 during the last glacial (e.g. Abrantes, 2000; Lebreiro et al., 1997); this zone today is characterised

313 by a seasonal upwelling system (Peliz et al., 2005) and Brigantedinium spp. percentages only

314 reach a maximum of $2-5 \%$ in the modern database. Percentages of these cysts fluctuate more in

315 the Alboran Sea, with pronounced oscillations (average of 19\% and peaks reaching 30 to $45 \%$ )

316 (Fig. 2a).

\section{4.1. Dinocysts occurring during Greenland Stadials}


320 Dinocysts which feature prominently during GS include Bitectatodinium tepikiense, Spiniferites

321 lazus, Spiniferites elongatus, Impagidinium aculeatum, and Operculodinium centrocarpum in the

322 Alboran Sea (Fig. 2a), and B. tepikiense, S. elongatus, cysts of Pentapharsodinium dalei,

323 Lingulodinium machaerophorum and Nematosphaeropsis labyrinthus on the SW Iberian margin

324 (Fig. 2b). It is also interesting to note that maximal dinocyst concentrations occur during GS off

325 Portugal (most notably during HS 4; Fig. 2b) contrarily to what we observe in the Alboran record 326 (Fig. 2a).

In the Alboran Sea, B. tepikiense increases during HS events, especially HS 3 and HS 4 (Fig. 2a),

329 whereas it occurs during each GS on the SW Iberian margin, where it consistently makes up

330 almost $10 \%$ of the total dinocyst assemblage (Fig. 2b). Today, B. tepikiense is mainly distributed

331 between $40^{\circ} \mathrm{N}$ and $60^{\circ} \mathrm{N}$ in temperate to sub-arctic environments of the North Atlantic, with the

332 highest abundances found south of the Gulf of St. Lawrence in coastal environments of Nova

333 Scotia and the Gulf of Maine (Wall et al., 1977; Mudie, 1992). This species is characteristic of

334 areas marked by strong seasonal contrasts, with freezing winter SSTs and up to $16^{\circ} \mathrm{C}$ summer

335 SST (Rochon et al., 1999; de Vernal et al., 2005), and enhanced surface water stratification

336 (Rochon et al., 1999; Marret and Zonneveld, 2003). Previous results from the North Atlantic

337 (Zaragosi et al., 2001; Penaud et al., 2009), the SW Iberian margin (Sánchez-Goñi et al., 2000;

338 Turon et al., 2003), and the western Mediterranean Sea (Turon and Londeix, 1988; Combourieu-

339 Nebout et al., 2002) have shown increased abundances of B. tepikiense during HS.

341 S. elongatus develops during each GS with low percentages reaching 2-5\% in the Alboran Sea

342 (Fig. 2a) and 1-2\% on the western Iberian margin (Fig. 2b). Maximum present-day occurrences

343 of this species are observed in the Baffin Bay and Barents Sea, and this taxon is generally related 
344 to cool to temperate conditions (Rochon et al., 1999). The significant occurrence of $B$. tepikiense

345 and S. elongatus is attributed to strong seasonality characterised by winter sea-surface

346 temperatures probably less than $5^{\circ} \mathrm{C}$ (Marret et al., 2004).

348 Cysts of $P$. dalei occur sporadically in the Alboran Sea core (Fig. 2a) but mark clearly the cold 349 events in core MD95-2042, most notably HS 2 and HS 4 (Fig. 2b). Cysts of P. dalei are well 350 represented in modern sediments from polar to subpolar environments that experience summer 351 sea-surface temperatures higher than $4^{\circ} \mathrm{C}$ (Rochon et al., 1999; Matthiessen, 1995; Marret et al., 352 2004; de Vernal et al., 2005). They are particularly prevalent as part of the spring bloom within 353 North Atlantic fjord systems (Dale, 1977; Harland et al., 2004a,b).

In the Alboran Sea, we show that $S$. lazus is associated with cold HS and especially HS 5 (Fig. 2a). Today, the distribution of S. lazus is restricted to coastal regions of western Europe, always with low abundances (less than $2 \%$ of the dinocyst assemblages) (Reid, 1974). This species can be regarded as a neritic temperate species of regions characterised by oligotrophic to eutrophic surface water conditions (Reid, 1974; Harland, 1983).

361 Finally, the most striking feature visible in the dinocyst distribution during the D-O cycles is the systematic occurrence of Impagidinium aculeatum during GS in the Alboran Sea, with low

363 percentages reaching a maximum of 5\% (Fig. 2a). On the western Iberian margin, this species 364 peaks during GI, although a local maximum is also observed during HS 5 (Fig. 2b). At present, 365 this taxon is associated with warm water dinocyst assemblages; high relative abundances are 366 found in tropical/subtropical oligotrophic open oceanic sites (Turon, 1984). In SW Iberian and 367 western Mediterranean paleoclimate records, this species is characteristic of the Holocene with 
368 percentages close to 20\% (Combourieu-Nebout et al., 1998; Turon et al., 2003; Rouis-Zargouni 369 et al., 2010). However, percentages close to 5\% were also previously observed during cold stadials (HS 1 and HS 2) in a core from the Sicilian-Tunisian Strait (Rouis-Zargouni et al., 2010).

\subsection{Dinocysts occurring during Greenland Interstadials}

Dinocysts which feature prominently during GI in the Alboran Sea include Spiniferites mirabilis, Impagidinium patulum, L. machaerophorum, N. labyrinthus as well as some heterotrophic species (Protoperidinioids, Selenopemphix nephroides and Selenopemphix quanta, but excluding Brigantedinium spp. whose ecology is rather complex) (Fig. 2a). On the SW Iberian margin they include Impagidinium species (I. aculeatum and I. patulum), S. mirabilis, O. centrocarpum and S. nephroides (Fig. 2b). Unlike the SW Iberian margin (Fig. 2b), maximal dinocyst concentrations occur during GI in the Alboran Sea (especially during GI 8 and GI 12; Fig. 2a).

In the Alboran Sea, GI are characterised by the species S. mirabilis (Fig. 2a) with percentages on average four times higher than on the SW Iberian margin (Fig. 2b). The highest relative abundances of S. mirabilis are recorded during GI 7 and GI 8. Today, S. mirabilis is mainly distributed between $35^{\circ} \mathrm{N}$ and $50^{\circ} \mathrm{N}$ in warm temperate to temperate environments of the North Atlantic with highest occurrences found off the coast of Portugal and in the Bay of Biscay (Rochon et al., 1999). This species extends as far south as $10^{\circ} \mathrm{N}$ and is generally absent from areas with summer SST below $12^{\circ} \mathrm{C}$ and salinity below 28.5 , and thrives optimally when winter

389 SSTs are between $10^{\circ} \mathrm{C}$ and $15^{\circ} \mathrm{C}$ and summer SSTs are above $15^{\circ} \mathrm{C}$.

391 On the SW Iberian margin, GI are characterised by I. patulum (Fig. 2b) with abundances four 
392 times higher than in the Alboran Sea (Fig. 2a). Most Impagidinium species occur today with

393 maximum frequencies in tropical to warm temperate waters between $20^{\circ} \mathrm{N}$ and $35^{\circ} \mathrm{N}$ and are

394 representative of full-oceanic conditions (Harland, 1983; Turon, 1984; Bouimetarhan et al., 395 2009).

397 Spiniferites delicatus is common on the SW Iberian margin and is mainly linked with interstadial 398 conditions (Fig. 2b), while it is rare in the Alboran Sea (Fig. 2a). S. delicatus is a temperate 399 species adapted to warm and neritic conditions (Wall et al., 1977; Harland, 1983; Marret, 1994).

401 S. quanta, S. nephroides and some Protoperidinioids show a distribution pattern closely linked to 402 GI in the Alboran Sea (Fig. 2a). This association also holds for S. nephroides on the SW Iberian 403 margin, but is less obvious for $S$. quanta and Protoperidinioids as they also increase during GS 404 (Fig. 2b). These latter taxa, represented by low relative abundances in the modern database and a 405 scattered distribution in the North Atlantic (Rochon et al., 1999), are derived from heterotrophic 406 dinoflagellates and are mainly related to high food resources. Their heterotrophic strategy of 407 nutrition probably links them to the presence of higher concentrations of nutrients in surface 408 waters. S. quanta has previously been linked to the dynamics of upwelling cells off NW Africa 409 (Dodge and Harland, 1991; Penaud et al., 2010).

411 4.3. Opposite dinocyst patterns between Iberian and Alboran environments over D-O cycles

413 Other dinocyst species not described above, L. machaerophorum, $N$. labyrinthus, and $O$.

414 centrocarpum, are an important component of the dinocyst assemblages and show opposite 415 patterns in both cores 
417 N. labyrinthus shows very high percentages in the Alboran Sea (average 24\%), where it occurs 418 generally within GI (Fig. 2a). Peaks of this species systematically exceed $40 \%$ and can reach 60 419 to $70 \%$ of the total dinocyst assemblage. On the SW Iberian margin, this taxon is less prevalent 420 (average of 4.5\%) with peaks generally reaching 10\% during GS (except during HS) (Fig. 2b). At 421 present, $N$. labyrinthus is a typical open-ocean species found predominantly between $45^{\circ} \mathrm{N}$ and $65^{\circ} \mathrm{N}$ in the North Atlantic Ocean (Rochon et al., 1999; Matthiessen, 1995; Marret et al., 2004; de

423 Vernal et al., 2005). Maximum abundances of this species are recorded off southern Greenland 424 where cold waters from the East Greenland and Labrador currents mix with warm North Atlantic waters of the Irminger Current (Rochon et al., 1999; Marret et al., 2004). This species, in association with $B$. tepikiense, was previously related to polar water incursions during MIS 5 cold substages off Portugal (Sánchez-Goñi et al., 1999; Eynaud et al., 2000), and during the Younger

428 Dryas off Portugal (Turon et al., 2003), in the Mediterranean (Turon and Londeix, 1988; Rouis429 Zargouni et al., 2010) and off NW Morocco (Marret and Turon, 1994; Penaud et al., 2010). N. 430 labyrinthus has also been positively correlated with nutrient-rich and cool waters (Turon and 431 Londeix, 1988; Devillers and de Vernal, 2000).

437 is also found in abundance in North African coastal upwelling regions (Targarona et al., 1999;

438 Sprangers et al., 2004) and near the Congo outlet (Marret, 1994). Extremely high concentrations 439 of these cysts have been found in areas with typical seasonally stratified water columns such as 
440 fjords, bays, and estuaries (e.g. Reid, 1972; Bradford and Wall, 1984; Dale, 1985; Lewis, 1988;

441 Morzadec-Kerfourn, 1988; Dale et al., 1999). This taxon has often been related to warm and 442 stratified surface waters (Marret and Zonneveld, 2003), and has also been used as a proxy for 443 fluvial inputs towards the ocean (Zaragosi et al., 2001; Holzwarth et al., 2010).

445 O. centrocarpum occurs frequently in the Alboran Sea record with percentages reaching 20 to $44640 \%$ during almost every GS (Fig. 2a). On the SW Iberian margin, this species shows relatively 447 low percentages, with peaks generally less than 10\% during GI and reaching a maximum of $20 \%$ 448 during GI 3 (Fig. 2b). This species is considered to be a cosmopolitan, cool to temperate taxon

449 (Turon, 1984; Rochon et al., 1999; Marret and Zonneveld, 2003), and an abundance pattern 450 following the route of the North Atlantic Drift (NAD) has been identified from its present 451 geographical distribution in North Atlantic surface sediments (Turon, 1984; Rochon et al., 1999). 452 This observation was previously used to interpret the presence of an active NAD at times when 453 this species was abundant in the Quaternary North Atlantic sediments (Zaragosi et al., 2001; 454 Eynaud et al., 2004; Penaud et al., 2008, 2009).

\section{Temperature and salinity records: convergences and discrepancies}

\subsection{SST: dinocysts versus planktonic foraminifera}

460 Quantitative reconstructions derived from the two transfer functions (dinocyst and foraminifera)

461 are not directly comparable since the reconstructed parameters are not exactly the same. The 462 dinocyst transfer function 3PBase-940 only provides February and August SST reconstructions 463 while the foraminiferal transfer function R-1007 only provides annual and seasonal-mean (i.e. 
464 winter, spring, summer and fall) SST reconstructions. However, February and August

465 foraminiferal SST can be estimated using the MAT transfer function derived from Pflaumann et 466 al. (1996) which relies on a modern database of 692 modern assemblages (only Atlantic stations), 467 improved during the MARGO project (Kucera et al., 2005). It is, however, more appropriate for 468 us to discuss the foraminiferal data from the R-1007 transfer function (Atlantic and 469 Mediterranean modern databases) for the Alboran Sea core which is located at the boundary of 470 the two basins. The comparison of winter versus February SST values on the 664 common 471 stations from the foraminiferal north Atlantic databases $(n=1007$ versus $n=692)$ generates a mean 472 difference of $0.26^{\circ} \mathrm{C}$ (with a maximum difference of $1.95^{\circ} \mathrm{C}$ ). For the summer versus August SST 473 values, the mean difference is $0.37^{\circ} \mathrm{C}$ (with a maximum difference of $1.1^{\circ} \mathrm{C}$ ). These values are 474 within the range of the error bars of the foraminiferal reconstructions and therefore encourage us 475 to consider that monthly and seasonal foraminiferal SST values can be discussed interchangeably. 476 Concerning dinocysts, the $\mathrm{n}=940$ database also includes Mediterranean stations. It is worth noting 477 that, among the 84 Mediterranean analogues (including 17 stations in the Alboran Sea), the only 478 Mediterranean analogue found by the transfer function is located in the Alboran Sea and named 479 "M1039" (Fig. 1; Appendix B). This is mainly the case during GI conditions (GIs 3, 5, 7, 8, 9, 48011,12 and 13; cf. Appendix B), suggesting that GI conditions in the Alboran Sea between 25 and 48150 ka were roughly equivalent to conditions prevailing at the "M1039" site today (Fig. 1).

483 When comparing SST reconstructions from both micropaleontological proxies on the two cores, 484 one can note that February versus winter SST values obtained with dinocysts (3PBase-940) and 485 foraminifera (R-1007), respectively, are closer than August versus summer ones (Fig. 3).

486 However, the general good consistency of February versus winter SST is not valid for the SW 487 Iberian margin during HS 5 with about $8^{\circ} \mathrm{C}$ difference between both micropaleontological 
488 reconstructions (dinocyst SST estimates around $13^{\circ} \mathrm{C}$ and foraminiferal ones close to $5^{\circ} \mathrm{C}$; Fig.

489 3). This offset is unrealistically large given the prediction error for each method (around $1.2^{\circ} \mathrm{C}$ ).

490 This minor SST drop expressed in dinocyst populations may be underestimated, as also revealed

491 by the annual alkenone-derived SST values warmer than the February dinocyst-based SST ones

492 (Fig. 3). One reason may come from the occurrence of the dinocyst species Impagidinium

493 aculeatum during HS 5 (Fig. 2). Indeed, on the western Iberian margin, this species peaks during

494 GI, although a local maximum is observed during HS 5 (percentages slightly higher than 5\%).

495 However, this species is associated with warm water dinocyst assemblages and is found today in 496 tropical/subtropical oligotrophic open oceanic sites (Turon, 1984). Although the occurrence of 497 this taxon during a cold HS is not understood, it may switch the transfer function towards warmer 498 SST values.

500 August versus summer SST reconstructions for both cores show similar overall trends but differ 501 more in terms of amplitudes, with dinocyst SSTs being 5 to $10^{\circ} \mathrm{C}$ higher than foraminiferal SST 502 estimates (Fig. 3). Two hypotheses can be put forward with respect to this observation. Either the 503 August/summer (dinocyst or/and foraminiferal) quantifications are less reliable or the 504 discrepancy reflects an ecological bias. Dinocysts are indeed produced by dinoflagellates that 505 thrive in the photic zone while foraminifera can migrate deeply in the water column with living 506 depths ranging from 0 to $1000 \mathrm{~m}$. Dinoflagellates, being found in shallower water, would thus 507 record warmer SST consistently with a higher stratification during the warmest month, i.e.

508 August. Various biases between different micropaleontological reconstructions can thus occur in 509 relation to the ecological strategy (depth of habitat and growth seasons) of the different

510 planktonic populations (de Vernal et al., 2005). The following comparison with alkenones will 511 help us to decipher whether the foraminiferal or dinocyst signal is too cold or warm, respectively. 
512 Finally, concerning the Alboran Sea core, one can note that dinocysts and foraminiferal show

513 closer August versus summer SST values between 31 and $38 \mathrm{ka}$ and larger offsets between 38

514 and $50 \mathrm{ka}$. This point will be further discussed in section 6.2.3. of this manuscript.

\subsection{SST: transfer functions versus alkenones}

Alkenone-derived SST from cores MD95-2043 (Cacho et al., 1999) and MD95-2042 (Pailler and Bard, 2002) has previously been compared with ice-core records, demonstrating a close linking between SSTs in the western Mediterranean and temperature developments over the wider North

521 Atlantic region, including Greenland. Here, it appears that our dinocyst-based SST

522 reconstructions for both cores match peak to peak with the SSTs derived from alkenones, 523 showing minimum values during GS (Fig. 3). Furthermore, the alkenone-based SST, which 524 records an annual signal of temperature, fluctuates systematically in between the temperature 525 range given by seasonal dinocyst SST reconstructions and is closer to February than August SST 526 (Fig. 3). A co-variation between February dinocyst SST and alkenone-derived SST reconstructions was previously observed off NW Morocco during the last glacial over the last 30

528 ka (Penaud et al., 2010). This would confirm the hypothesis that switches in mean annual 529 temperatures were dominated by, and thus weighted towards, the winter season during the last 530 glacial cycle as suggested by Denton et al. (2005).

532 The foraminiferal transfer function $n=1007$ also provides annual SST reconstructions that can

533 directly be compared with the alkenone signal. One can note that annual SST values

534 reconstructed with both proxies are closer during GI than during GS (Fig. 3). Foraminifera

535 routinely provide much colder temperatures during GS, and especially during HS that are 
536 characterised by significant SST anomalies between 4 and $7^{\circ} \mathrm{C}$ (Fig. 3). This shift of annual SST

537 values towards cold SSTs is mainly due to extremely cold summer SSTs reconstructed with

538 foraminifera during GS (Fig. 3). This contrast has parallels to the previous observation on the

539 considerable offsets between dinocyst and foraminiferal August versus summer SST. Since

540 alkenones are synthesised by coccolithophorids which are single-celled algae, protists and

541 phytoplankton such as dinoflagellates, we can assume that they both give a signature of sea-

542 surface hydrological changes occurring in the photic zone, while foraminifera may yield a bias

543 towards colder SSTs, especially during GS. However, it will be crucial to understand if this

544 finding reflects a real ecological strategy of foraminifera (different depths of habitat following

545 different seasons) or a problem associated with the transfer function.

547 5.3. SSS: dinocyts versus planktonic foraminifera

549 Quantifications of salinity are of critical interest as they are fairly rare in paleoclimate studies. A 550 major challenge in paleoceanography is to increase the availability of SSS reconstructions for 551 comparison with climate models (e.g. MARGO project members, 2009). In our records, similar 552 changes, both in amplitude and timing, are revealed through the comparison of February 553 dinocyst-based SSS versus winter foraminiferal derived ones (Fig. 3). Numerical results are 554 always very close or at least within the prediction error of 1-1.8 psu, except during HS 5 and GI 55512 at the SW Iberian margin which are marked by differences of 2 to 3 psu between both 556 micropaleontological proxies (Fig. 3). Comparison of the February/winter SSS data is 557 particularly striking because the methods of quantification are different. One method requires 558 MAT calculation of SST based on planktonic foraminifera and $\delta^{18} \mathrm{O}$ analysis (e.g. Malaizé and 
559 Caley, 2009), while the other one is obtained on the basis of MAT transfer function applied to

560 dinocyst assemblages (e.g. de Vernal et al., 2005). However, correlations between fluctuations in

561 August dinocyst-based SSS and summer foraminiferal derived ones are less evident with

562 fluctuations similar in timing but divergent in terms of amplitudes, especially for the Alboran Sea

563 (Fig. 3).

565 For the SW Iberian margin, our study shows that major low salinity events are recorded during 566 HS (Fig. 3b). HS 4 displays the maximum drop in February/winter SSS with values reaching 31

567 psu, corresponding to the largest fluxes of freshwater to the ocean over our study period. Our data

568 for HS 3 (around 31.5-32.5 psu, 4 psu lower than the modern value) also show a major low

569 salinity event and are consistent with previous results acquired further north along the Celtic

570 margin over the last $35 \mathrm{ka} \mathrm{BP}$ where this interval was also characterised by a 4 psu depletion in

571 SSS (Eynaud et al., submitted).

572 For the Alboran Sea, the difference in the resolution of analysis between dinocyst and

573 foraminiferal/isotope reconstructions makes it difficult to compare some sections (Fig. 3a). This

574 is mainly due to the fact that foraminiferal SSS is calculated from both foraminiferal SST and

575 planktonic $\delta^{18} \mathrm{O}$ data and the resolution of the $\delta^{18} \mathrm{O}$ record is lower than the foraminiferal SST

576 record. For the whole Alboran Sea record, February/winter SSS shows changes of similar order

577 of magnitude between each GS, with the strongest signal of freshening recorded during HS 4

578 reaching 33 psu (4 psu lower than the modern value). 


\subsection{The new contribution of dinocyst assemblages in the Alboran Sea}

\subsubsection{Warm intervals (GI) in the Alboran Sea}

During GI, we observe an expansion of warm temperate to tropical species with a trend of decreasing abundance, and decreasing February and alkenone SST, from immediately prior to a Heinrich Stadial to the next HS (Fig. 4). This pattern is similar to that seen in the Greenland ice core isotope records showing progressively shorter GI and smaller increases in Greenland air temperatures between HS 5 and HS 4 and between HS 4 and HS 3 (Fig. 4, NGRIP GICC05).

591 This demonstrates a similar trend between Alboran SST and atmospheric temperatures over

592 Greenland, involving a rapid transmission of Northern Atlantic climate changes into the western 593 Mediterranean region.

594 When comparing the amplitude of warm taxa development during individual D-O warming (Fig.

595 4), we note less frequent occurrences of thermophilous taxa during the earlier interstadials (GI 596 12-9) than during the subsequent interstadials (GI 8-5). This is consistent with pollen analysis 597 conducted on the same core (Fletcher and Sánchez-Goñi, 2008) demonstrating high values for 598 Mediterranean forest during GI 8, 7,6 and 5 reflecting the maximum in subtropical summer 599 insolation associated with the precession minimum centred around 30-35 ka (Fig. 4). Such a 600 development is also seen in paleo-vegetation records at nearby Alboran site ODP 976 601 (Combourieu-Nebout et al., 2002) and on the SW Iberian margin (MD95-2042: Sánchez-Goñi et 602 al., 2000).

603 The interstadials GI 8 and GI 12, immediately succeeding HS 4 and HS 5, respectively, exhibit 604 particularly long and warm periods. They are both marked by high relative abundances of warm 605 water dinocysts, high SST estimates (especially clear with alkenones; Fig. 4), and by the highest 
606 paleoproductivity conditions indicated by heterotrophic taxa in the early interstadials and high

607 dinocyst concentrations in the second half of GI 8 and GI 12 (Fig. 4). In terms of sea-surface

608 paleohydrology, GI 8 and GI 12 are thus very similar with a comparable bipartite structure (Fig.

609 4). Palynological investigations of GI 8 and GI 12 in the same Alboran Sea core showed that

610 these periods were characterised by the strongest expansions of mixed oak forest between 48 and

61115 ka (Fletcher and Sánchez-Goñi, 2008). Furthermore, Fletcher and Sánchez-Goñi (2008)

612 identified an Atlantic oceanic character during GI 12, in contrast to a markedly Mediterranean

613 character during GI 8, linked to the precession minimum that likely enhanced the Mediterranean

614 climate and caused an enhanced seasonal contrast between dry summers and wet winters

615 (Sánchez-Goñi et al., 2008, 2009; Fletcher and Sánchez-Goñi, 2008). Our dinocyst data also

616 reveal a strong expansion of the species L. machaerophorum in the second half of GI 8,

617 representing between 20 and $40 \%$ of the total dinocyst assemblage (Fig. 4). This species has

618 sometimes been used to trace fluvial inputs (Zaragosi et al., 2001; Holzwarth et al., 2010) and

619 could reflect higher river run-off to the Alboran Sea, providing further evidence for increased

620 winter precipitations during this interval.

621 Throughout our record, heterotrophic dinocyst species (S. nephroides, S. quanta, and

622 Protoperidinioids cysts) occur during each GI in the Alboran Sea (Fig. 4). Their occurrences

623 suggest sea-surface conditions characterised by increased productivity (Rochon et al., 1999), as

624 also indicated by increased total dinocyst concentrations (Fig. 4). This general pattern of higher

625 productivity during GI relative to GS has previously been discussed based on geochemical

626 evidence (calcium carbonate, barium excess, and total organic carbon) from the same core

627 (Moreno et al., 2004). Today, the two semi-permanent anticyclonic gyres found in the Alboran

628 Sea represent energetic mesoscale features and the main forcing maintaining these gyres is the

629 Atlantic jet which enters through the Strait of Gibraltar (Bormans and Garret, 1989; Benzohra 
630 and Millot, 1995; Garcia-Lafuente et al., 1998; Macias et al., 2008). The intensity of the jet is

631 typically modulated by atmospheric pressure variations over the western Mediterranean. Indeed,

632 when atmospheric pressures are lower than average, configuration close to a NAO negative

633 mode, westerlies prevail above the Mediterranean, the Atlantic jet flows northward near the

634 Spanish coast and the western Alboran gyre is well developed in the entire western Alboran Sea.

635 The opposite (NAO positive mode) occurs when easterly winds prevail, the inflow of Atlantic

636 waters is lower and the Atlantic jet is directed southward, reducing the western Alboran gyre

637 extent (Candela et al., 1989; Garcia-Lafuente et al., 2002; Macias et al., 2008). At an annual

638 scale, on the basis of satellite imagery analysis (e.g. Garcia-Gorriz and Carr, 1999; Baldacci et

639 al., 2001; Macias et al., 2007, 2008) maximum surface chlorophyll concentrations were usually

640 found in winter and minimum values were observed in summer (July and August). Biological

641 patterns are thus also tightly coupled to atmospheric pressure above the Mediterranean Basin with

642 westerlies being shifted southward during winter. At the millennial-scale resolution of our study

643 and in agreement with Moreno et al. (2004), our data suggest that GI conditions would exhibit a

644 prolonged southward shift of the westerly wind belt, inducing a more intense Atlantic surface jet

645 that favoured gyre-induced upwelling in the Alboran Sea.

\section{6.1.2. Cold intervals (GS) recorded in the Alboran Sea}

649 The association B. tepikiense - S. elongatus represents an indicator for the incursion of subpolar 650 water masses at the Alboran site that is highly evident during HS (Fig. 4). This latter pattern is

651 similar to that of the subpolar foraminifera Neogloboquadrina pachyderma s. recorded in the

652 same core (Cacho et al., 1999) that shows higher percentages during HS (Fig. 4). This

653 foraminifer displays the highest percentages during HS 4, then HS 3 and finally HS 5, while $B$. 
654 tepikiense shows higher percentages during HS 3 compared to HS 4 (cf. Figs. 2 and 4). $B$.

655 tepikiense is absent from the Mediterranean Sea today, and highest abundances of this species

656 occur in areas characterised by high-amplitude $\left(10^{\circ} \mathrm{C}\right)$ seasonal temperature shifts (Rochon et al.,

657 1999). Therefore, its occurrence during HS in Alboran Sea surface waters implies enhanced

658 seasonal temperature contrast $\left(15^{\circ} \mathrm{C}\right.$; cf. Fig. 5) compared to the present-day one (i.e. $10^{\circ} \mathrm{C}$;

$65923.5^{\circ} \mathrm{C}$ in summer and $14.5^{\circ} \mathrm{C}$ in winter; cf. Fig. 5), caused by a strong decrease of winter SST

660 (Fig. 4). Our February dinocyst SST reconstructions reinforce this hypothesis by showing low

661 SST with values around $5.5^{\circ} \mathrm{C}$ and $6.5^{\circ} \mathrm{C}$ during HS 4 and $\mathrm{HS} \mathrm{3}$, respectively, i.e. $9^{\circ} \mathrm{C}$ less than at

662 present (Fig. 4). It is thus important to note that, in contrast to N. pachyderma s., B. tepikiense

663 does not mark systematically colder intervals but intervals with larger seasonal contrasts. Our

664 results are also in agreement with other observations made at ODP Site 976 (Alboran Sea) that

665 reflect coeval increases of B. tepikiense with $N$. pachyderma s. percentages during HS, over the

666 last 50 ka BP (Turon and Londeix, 1988; Combourieu-Nebout et al., 2002). Our data thus

667 confirm that sea-surface cooling in the Alboran Sea was mainly linked to the advection of cold

668 Atlantic water to the western Mediterranean (Cacho et al., 1999). Such cold-water advection

669 occurred synchronously with regional cooling related to atmospheric conditions over the western

670 Mediterranean (Combourieu-Nebout et al., 2002; Sánchez-Goñi et al., 2002). Indeed, on the

671 adjacent continent, the Mediterranean forest (i.e. temperate taxa) collapsed (Fig. 4) and estimated

672 winter atmospheric conditions indicate a $10^{\circ} \mathrm{C}$ lowering and a decrease of $400 \mathrm{~mm}$ in

673 precipitation (Sánchez-Goñi et al., 2002).

674 The HS configuration contrasts with the other GS. In the Alboran Sea, before or during each GS

675 (especially those not associated with HS conditions) we note pronounced peaks of $O$.

676 centrocarpum (Fig. 4). The occurrence of O. centrocarpum in the Alboran Sea, whose present-

677 day distribution directly mirrors the flow path of the NAD, may result from the influx of cool 
678 North Atlantic waters entering into the Mediterranean; temperatures of these waters, while

679 presumably low, remained above those of the subpolar waters that entered the Mediterranean

680 during HS. GS events of the last glacial have been demonstrated to coincide with intensification

681 of the deep circulation in the Mediterranean (Cacho et al., 2000, 2006; Sierro et al., 2005; Frigola

682 et al., 2008). Our data suggest that the intensification of deep ventilation in the Alboran Sea,

683 reflected in benthic $\delta^{13} \mathrm{C}$ data (Fig. 4; Cacho et al., 2006), was synchronous with the advection of

684 North Atlantic waters to the Mediterranean, as reflected by highest relative abundances of cool-

685 water dinocyst taxa (Fig. 4).

686 We demonstrate two different patterns during GS: those associated with HS are marked by

687 increased abundances of cold water species associated with subpolar waters, and those not

688 associated with HS are marked by an expansion of cool North Atlantic species. Interestingly, it

689 has been demonstrated that the densest Western Mediterranean Deep Water was formed during

690 GS not associated with HS (Cacho et al., 2006; Frigola et al., 2008). More precisely, it has been

691 suggested that a strong mode of overturning prevailed during GS not associated with HS, an

692 intermediate mode of overturning during HS and a weak mode of overturning during GI (Sierro

693 et al., 2005; Frigola et al., 2008). Strong overturning was expected during HS since strong and

694 cold northern continental winds prevailed over the Mediterranean resulting in dry-cold conditions

695 on land (Fig. 4; Combourieu-Nebout et al., 2002; Sánchez-Goñi et al., 2002). However, the HS

696 intermediate mode has been linked with a strong influence of subpolar waters that lowered sea-

697 surface salinity thus reducing deep water formation and favouring water column stratification

698 (Sierro et al., 2005). The observation of subpolar species (N. pachyderma s. and B. tepikiense)

699 during HS (especially HS 3 and HS 4), as well as the low winter and summer salinities

700 reconstructed from dinocysts, lowered by around 0.5 to 1.5 psu compared to the other GS in both 
701 seasonal configurations (Fig. 3), within low precipitation phases, reinforce the idea of sustained 702 cold conditions with subpolar water masses advection towards the Mediterranean Sea and 703 decreased deep water formation.

\subsection{Alboran Sea versus SW Iberian margin between 50 and 25 ka}

\subsubsection{SST reconstructions and paleoenvironmental signatures}

In both cores, lowest SST estimates are observed during HS 4 which represents the most

710 pronounced cold event between 25 and $50 \mathrm{ka}$, with February/winter SST of about $5.5^{\circ} \mathrm{C}$ and $4^{\circ} \mathrm{C}$

711 recorded in the Alboran Sea and the SW Iberian margin, respectively (Fig. 3). Previously, the

712 coldest deep water temperatures in the Alboran Sea (Cacho et al., 2006), maximum

713 concentrations of IRD off the Portuguese margin (Thouveny et al., 2000), and a significant

714 increase in the transport of Saharan dust (Moreno et al., 2002) were observed to occur during HS

715 4. This confirms the magnitude of HS 4 (cf. Eynaud et al., 2009) in terms of expansion of polar

716 waters towards the Iberian margin (i.e. February SST $11^{\circ} \mathrm{C}$ lower than modern ones) and even

717 towards the western Mediterranean (i.e. February SST $9^{\circ} \mathrm{C}$ lower than modern ones), in phase

718 with a nearly complete shutdown of the thermohaline circulation (Maslin et al., 1995; Elliot et al.,

719 2002; Roche et al., 2004).

720 HS 3 is marked by a change in surface hydrological conditions with February/winter SST of

721 about $6.5^{\circ} \mathrm{C}$ in the Alboran Sea and $5.5^{\circ} \mathrm{C}$ off Portugal (Fig. 3). Winter conditions seem thus to

722 have been less severe during HS 3 than HS 4, although they are nevertheless characterised in both 723 paleo-records by significant cooling. 
724 Finally, HS 5 is the event which displays the weakest changes both in the Alboran Sea and off

725 Portugal, where dinocyst February SST are about $9^{\circ} \mathrm{C}$ and $13^{\circ} \mathrm{C}$, respectively (Fig. 4). However, foraminiferal winter SST estimates are close to $6^{\circ} \mathrm{C}$ and $5^{\circ} \mathrm{C}$ in the Alboran Sea and off Portugal, respectively. Quantifications derived from transfer functions appear less reliable during this interval. The alkenone annual signal (around $10.5-11^{\circ} \mathrm{C}$ in the Alboran Sea and $12-12.5^{\circ} \mathrm{C}$ off Portugal) probably provide an intermediate signature between dinocyst-based (too warm) and foraminiferal-based (too cold) February/winter SST estimates.

Micropaleontological evidence in the subpolar North Atlantic has shown that abrupt SST changes associated with the D-O events in Greenland were matched by SST variations of at least $3-5^{\circ} \mathrm{C}$ (Bond et al., 1992, 1993; Elliot et al., 2002). In the subtropical North Atlantic, SST excursions of $4-5^{\circ} \mathrm{C}$ across stadial-interstadial transitions of the last glacial were recorded from the Bermuda Rise (alkenones: Sachs and Lehman, 1999; isotopes: Keigwin and Boyle, 1999) and off Portugal (alkenones: Bard et al., 2000; Martrat et al., 2007). SST changes of up to $6^{\circ} \mathrm{C}$ are also documented in the western Mediterranean (alkenones: Martrat et al., 2004), due to southward shifts in the position of the Polar Front. Consistently with these previous results, we show here that the Alboran Sea and the SW Iberian margin experienced fluctuations of dinocyst SST of around $5-6^{\circ} \mathrm{C}$ between GI and GS, except for HS events and more specifically HS 4 with a SST drop of around $11^{\circ} \mathrm{C}$ off Portugal and of $8^{\circ} \mathrm{C}$ in the Alboran Sea. This demonstrates the extreme sensitivity of dinocysts to climate fluctuations in subtropical latitudes.

\subsubsection{Multiproxy evidence for paleohydrological changes through time}

47 During GI, the expansion of the Mediterranean forest (Fig. 4) was attributed to atmospheric 
748 conditions close to present-day ones with warm summer and wet winter conditions over south-

749 western Europe (e.g. Sánchez-Goñi et al., 2002; Combourieu-Nebout et al., 2002; Bout-

750 Roumazeilles et al., 2007; Daniau et al., 2007). During those times, we show that warm

751 temperate species S. mirabilis and I. patulum expanded in the Alboran Sea and on the SW Iberian

752 margin, respectively (Fig. 4), and high SST is recorded at both sites during GI revealing sea-

753 surface conditions closer to present-day ones (Figs. 3 and 4).

755 During GS, the decline of the Mediterranean forest (Fig. 4) and the development of steppe and

756 semi-desert vegetation over the south-western European borderlands were attributed to

757 intensified winter dryness with cold continental conditions affecting the western Mediterranean

758 area (e.g. Sánchez-Goñi et al., 2002; Combourieu-Nebout et al., 2002; Moreno et al., 2002, 2005;

759 Roucoux et al., 2005; Bout-Roumazeilles et al., 2007; Daniau et al., 2007). At that time,

760 assemblages of cold-water dinocyst species, including B. tepikiense and S. elongatus developed,

761 reflecting cold-water advection along the SW Iberian margin and towards the Alboran Sea (Fig.

762 4). However, unlike the western Iberian margin where B. tepikiense occurs during each GS, $B$.

763 tepikiense expands principally in the Alboran Sea during HS, and especially during HS 3 and HS

764 4. In the western Mediterranean Sea, HS impacts were therefore greater than those associated

765 with the other GS. Broecker (2006) has compiled data from several areas and has identified sites

766 where the impact associated with North Atlantic Heinrich events is larger (eastern Brazil, central

767 Florida, Arabian Sea, Chinese stalagmites, and western Mediterranean area), in contrast to sites

768 where impacts are similar to those observed during the other stadials (Greenland ice and Cariaco

769 Basin). To explain this discrepancy, Broecker (2006) involves the greater magnitude of north-

770 hemispheric sea ice expansion associated with North Atlantic Heinrich events which exceeded

771 that associated with the other stadials. 
772 B. tepikiense was previously used to trace subpolar water masses on the western Iberian margin

773 (Eynaud et al., 2000; Turon et al., 2003) and in the Alboran Sea (Turon and Londeix, 1988;

774 Combourieu-Nebout et al., 2002) during HS. In our data, the observation of subpolar dinocysts in

775 both cores, in phase and synchronous with peaks of N. pachyderma s. (Fig. 4), confirms the idea

776 of the shift of the Polar Front (PF) towards southern latitudes during North Atlantic Heinrich

777 events. Indeed, Eynaud et al. (2009) proposed a conceptual scheme for the position of the PF on

778 the western Iberian margin during Heinrich events and its influence on the local hydrology, and

779 noticed that the protrusion of subpolar waters extended until approximately $40^{\circ} \mathrm{N}$. Core MD95-

$7802042\left(37^{\circ} 48^{\prime} \mathrm{N}\right)$, at the southern limb of the Ruddiman belt (i.e. between 40 and $55^{\circ} \mathrm{N}$;

781 Ruddiman, 1977), was affected by subpolar waters and iceberg discharges. However, it is

782 surprising to observe that the peaks of B. tepikiense are even larger during GS not associated with

783 HS on the SW Iberian margin. When considering dinocyst, foraminiferal, and especially

784 alkenone-based SST reconstructions, HS are characterised by the coldest temperatures (Figs. 3

785 and 4). We can therefore assume that temperatures were probably too cold during summer

786 months to permit the expansion of B. tepikiense. This hypothesis is reinforced by the large

787 excursions towards cold summer temperatures observed with dinocyst and foraminiferal SST

788 reconstructions (Fig. 3). The huge advection of subpolar waters down to the SW Iberian margin

789 during each GS, and especially HS, is furthermore reinforced by the dinocyst SSS reconstructions

790 that show a generally more pronounced influence of meltwater in this sector compared with the

791 westernmost part of the Mediterranean Sea (average salinity offset of around 1 psu between the

792 sectors; Fig. 3). This is especially true for HS 4, characterised by salinities of around 31 on the

793 SW Iberian margin and 33 in the Alboran Sea (Fig. 3). We thus show the pronounced impact of

794 subpolar waters affecting the SW Iberian margin during each GS and especially during HS, while

795 the Alboran Sea is only impacted by huge freshwater discharges during HS. 


\subsubsection{A first attempt to interpret the dinocyst seasonality signal}

799 Sea surface temperatures and precipitation are environmental parameters directly linked to 800 seasonality in the study region, and the difference between August and February SST estimates

801 derived from dinocysts may contain important information regarding the seasonality (Fig. 5).

802 Overall, the two cores show excursions in seasonality reconstructions towards a higher seasonal 803 contrast during GS due to extremely cold February SST recorded during these cold intervals. At 804 the SW Iberian margin, seasonal contrasts during GI appear similar to the present-day range, 805 while extremely pronounced seasonal contrasts of roughly similar magnitude are recorded during 806 each GS. The pattern of seasonality is very close to the relative abundance curve of $B$. tepikiense 807 (Fig. 5). In the Alboran Sea, higher seasonal contrasts are mainly noted during HS and also 808 correspond to higher percentages of B. tepikiense. It is not surprising to find parallels between 809 this species and the seasonal signal since highest abundances of this species are found in areas 810 today characterised by high-amplitude $\left(10^{\circ} \mathrm{C}\right)$ seasonal temperature shifts (Rochon et al., 1999).

811 In the Alboran Sea, it confirms the establishment of an enhanced seasonal temperature contrast 812 compared to the present-day caused by a strong decrease in winter SST during HS (Combourieu813 Nebout et al., 2002). At the SW Iberian margin, it reveals very clearly the marked shift between 814 seasonal temperatures during each GS.

815 In the Alboran Sea, another climatic trend is superimposed on the general observations made 816 above with, in broad terms, stronger seasonal contrasts during the early part of the record 817 between 50 and $38 \mathrm{ka}$, compared to the period 38-31 ka (Fig. 5). Since seasonality and precession 818 are closely linked, we show the precession curve (Berger and Loutre, 1991) alongside the 819 reconstruction of seasonality (Fig. 5). It appears that lower seasonal contrasts are observed during 
820 the precession minimum and vice versa (Fig. 5). We would have expected higher seasonal

821 contrasts during the precession minimum since this orbital parameter enhanced the Mediterranean 822 climate with warmer summer and wetter winters (Meijer and Tuenter, 2007). When looking at

823 February SST reconstructions in the Alboran Sea, one can note that fluctuations during GS and

824 GI are of similar magnitude (Fig. 5). The contrast is mainly due to August SST reconstructions

825 that show colder values between HS 4 and HS 3 than between HS 5 and HS 4. Our data would

826 suggest a link between the Alboran Sea paleohydrology and the precession signal through a

827 climatic forcing acting on August temperatures. A first hypothesis could involve the general

828 strengthening of the gyre-induced upwelling in the Alboran Sea during the time interval 38-31 ka

829 favouring a cooling of sea-surface waters compared to the period 50-38 ka. However, the

830 functioning of the gyres is mainly controlled today by winter conditions. Furthermore, no large

831 differences are observed between 50-38 ka and 38-31 ka in terms of total dinocyst concentrations

832 and heterotrophic dinocyst species, these latter proxies indicating paleoproductivity conditions

833 probably connected to gyre-induced upwelling intensity. Greater stratification of the Alboran

834 water column may also be suggested for the period 50-38 ka compared to the period 38-31 ka on

835 the basis of the observation of dinocyst and foraminiferal August/summer SST (Fig. 3). Indeed,

836 SSTs in August and summer are similar between 38 and $31 \mathrm{ka}$ and are more distinct between 50

837 and $38 \mathrm{ka}$ (Fig. 3). This might suggest a greater stratification of water masses during summers

838 within the interval 50-38 ka and a stronger mixing of water masses during summers within the

839 interval 38-31 ka. Warmer dinocyst SSTs might relate to sea-surface conditions while

840 foraminiferal SSTs would incorporate SST signals at greater depths in the water column for the

841 period 50-38 ka. Further investigation will be necessary to verify and explore on longer time-

842 scales: a) the imprint of precession on the seasonality changes inferred from dinocysts, and b) the

843 functioning of the mesoscale energetic features in the Alboran Sea represented by two 
844 anticyclonic gyres today. 


\section{CONCLUSION}

847 We have characterised glacial climate variability between 25 and $50 \mathrm{ka}$ BP by comparing surface 848 paleohydrology signals on both sides of the Strait of Gibraltar (Alboran Sea and SW Iberian 849 margin). Comparison of dinocyst assemblages enables the reconstruction of hydrological features 850 at both locations and we present, in this study, the first quantitative dinocyst reconstructions (SST 851 and SSS) for MIS 3 obtained at mid-latitudes. Our hydrological quantifications acquired for both 852 cores reproduce millennial-scale changes correlated to the D-O climatic variability, with a pattern 853 of marked decrease in SST accompanied by a strong freshening of sea-surface waters evident 854 during each GS on the SW Iberian margin and during HS in the Alboran Sea. Furthermore, we 855 show similar patterns and amplitudes in SST reconstructions based on dinocysts, foraminifera 856 and alkenones, and in SSS derived from dinocysts and foraminiferal SST coupled with planktonic $857 \delta^{18} \mathrm{O}$. Larger discrepancies between dinocyst and foraminiferal estimates occur for summer 858 reconstructions than for winter reconstructions, which are very similar in amplitude. We 859 furthermore show the occurrence of cold taxa (including B. tepikiense and S. elongatus) during 860 GS and the presence of thermophilous ones (S. mirabilis and Impagidinium spp.) during GI.

861 However, the amplitude of variation in these taxa is not equivalent at both sites. B. tepikiense 862 characterises each GS in the SW Iberian margin while it only develops during HS in the Alboran 863 Sea. This pattern reflects, in the Alboran Sea, the maximum climatic deterioration during HS and 864 the incursion of low-salinity subpolar waters to the western Mediterranean. During other GS (i.e. 865 excluding HS), conditions were less severe in the Alboran Sea as is reflected by the occurrence of 866 O. centrocarpum at very high relative abundances in the Alboran Sea and low values on the SW 867 Iberian margin. This species conceivably reflects the inflow of cool North Atlantic waters to the 
868 western Mediterranean, synchronously with stronger deep convection occurring at that time in the

869 western Mediterranean. Finally, expansions of temperate to tropical taxa testify to the installation

870 of warm sea-surface waters during GI. In the Alboran Sea, a high primary productivity pattern is

871 deduced from heterotrophic species and high total dinocyst concentrations, suggesting gyre-

872 induced upwelling due to prevailing southward-shifted westerlies above the Mediterranean at that

873 time. The functioning of the gyre on multi-millennial timescales has also been discussed in light

874 of seasonality reconstructions based on dinocysts. However, the relationships between gyre

875 dynamics, seasonality and precession need to be explored in longer records covering several

876 precession cycles. The dinocyst data thus exhibit regional trends and suggest distinct oscillations

877 of sea-surface temperature and salinity, documenting the combined influence of atmospheric and

878 hydrologic processes impacting on the western Mediterranean Sea and eastern subtropical

879 latitudes of the North Atlantic during the abrupt climatic events of MIS 3. 


\section{Acknowledgements}

Thanks to the French polar institute IPEV (Institut Paul Emile Victor), the captain and the crew of the Marion Dufresne and the scientific team of the 1995 IMAGES cruise. We wish to thank Mr. Y. Balut for his assistance at sea and M. Castera and O. Ther for invaluable technical assistance at the laboratory. We gratefully acknowledge the reviewers, whose comments have enabled us to greatly improve this manuscript. We thank W. Fletcher for improving the English language of the manuscript. This study was supported by the French CNRS and contributes to the EuroCLIMATE project RESOLUTION.

\section{References}

892 Abrantes, F., 2000. 200000 yr diatom records from Atlantic upwelling sites reveal maximum 893 productivity during LGM and a shift in phytoplankton community structure at $185000 \mathrm{yr}$. Earth 894 and Planetary Science Letters 176(1), 7-16.

896 Ambar, I., Serra, N., Brogueira, M.J., Cabecadas, G., Abrantes, F., Freitas, P., Goncalves, C.,

897 Gonzalez, N., 2002. Physical, chemical and sedimentological aspects of the Mediterranean 898 outflow off Iberia. Deep-Sea Research II 49, 4163-4177.

899

900 Aristegui, J., Alvarez-Salgado, X.A., Barton, E.D., Figueiras, F.G., Hernandez-Leon, S., Roy, C., 901 Santos, A.M.P., 2005. Chapter 23 : oceanography and fisheries of the Canary current/Iberian 902 region of the eastern North Atlantic (18a,E). In : Brink K.H. (ed.), Robinson A.R. (ed.) The sea : 
903 the global coastal ocean : interdisciplinary regional studies and syntheses. Harvard : Harvard

904 University Press, 877-931.

905

906 Baldacci, A., Corsini, G., Grasso, R., Manzella, G., Allen, J.T., Cipollini, P., Guymer, T.H.,

907 Sanith, H.M., 2001. A study of the Alboran sea mesoscale system by means of empirical

908 orthogonal function decomposition of satellite data. Journal of Marine Systems 29, 293-311.

909

910 Bard, E., Rostek, R., Turon, J.L., Gendreau, S., 2000. Hydrological impact of Heinrich events in

911 the subtropical northeast Atlantic. Science 289, 1321-1324.

912

913 Bard, E., Rostek, F., Ménot-Combes, G., 2004. Radiocarbon calibration beyond 20,000 14C yr

914 B.P. by means of planktonic foraminifera of the Iberian Margin. Quat. Res. 61, 204-214.

915

916 Bassinot, F., Labeyrie, L., 1996. IMAGES MD 101, a coring cruise of the R/V Marion Dufresne

917 in the North Atlantic and Norwegian Sea. Institut Français pour la Recherche et la Technologie

918 Polaires, Plouzané, pp. 217.

919

920 Benzohra, M., Millot, C., 1995. Characteristics and circulation of the surface and intermediate

921 water masses off Algeria. Deep-Sea Research I 42 (10), 1803-1830.

922

923 Berger, A., Loutre, M.F., 1991. Insolation values for the climate of the last 10 million years.

924 Quaternary Science Reviews 10 (4), 297-317. 
926 Béthoux, J.P., 1979. Budgets of the Mediterranean Sea. Their dependence on the local climate

927 and on the characteristics of the Atlantic waters. Oceanol. Acta 2, 157-163.

928

929 Béthoux, J. P., 1984. Paléo-hydrologie de la Mer Mediterranee au cours des derniers 20000 ans.

930 Oceanologica Acta 7, 43-48.

931

932 Bigg, G.R., Wadley, M.R., 2001. Millennial-scale variability in the oceans: an ocean modelling

933 view. J. Quat. Sci. 16, 309-319.

935 Bigg, G.R., Rohling, E.J., 2000. An oxygen isotope dataset for marine waters. Journal of

936 Geophysical Research 105, 8527-8535.

937

938 Bond, G., Heinrich, H., Broecker, W., Labeyrie, L., McManus, J., Andrews, J., Huon, S.,

939 Jantschik, R., Clasen, S., Simet, C., Tedesco, C., Klas, M., Bonani, G., Ivy, S., 1992. Evidence

940 for massive discharges of icebergs into the North Atlantic ocean during the last glacial period.

$941 \quad$ Nature 360, 245-249.

942

943 Bond, G., Broecker, W., Johnsen, S., McManus, J., Labeyrie, L., Jouzel, J., Bonani, G., 1993.

944 Correlations between climate records from North Atlantic sediments and Greenland ice. Nature

$945365,143-147$.

946

947 Bormans, M., Garret, C., 1989. A simple criterion for gyre formation by the surface outflow from

948 a strait, with application to the Alboran Sea. Journal of Geophysical Research 94 (C9), 12637-

94912644. 
951 Bouimetarhan, I., Marret, F., Dupont, L., Zonneveld, K., 2009. Dinoflagellate cyst distribution in 952 marine surface sediments off West Africa $\left(6-17^{\circ} \mathrm{N}\right)$ in relation to sea-surface conditions, 953 freshwater input and seasonal coastal upwelling. Marine Micropaleontology 71, 113-130.

955 Bout-Roumazeilles, V., Combourieu Nebout, N., Peyron, O., Cortijo, E., Landais, A., Masson956 Delmotte, V., 2007. Connection between South Mediterranean climate and North African 957 atmospheric circulation during the last 50,000 yr BP North Atlantic cold events. Quaternary 958 Science Reviews 26 (25-28), 3197-3215.

960 Bradford, M.R., Wall, D.A., 1984. The distribution of Recent organic walled dinoflagellate cysts 961 in the Persian Gulf, Gulf of Oman, and north-western Arabian Sea. Palaeontographica 192(B), 196284.

963

964 Broecker, W.S., 2006. Abrupt climate change revisited. Global and Planetary Change 54, 211965215.

966

967 Cacho, I., Grimalt, J.O., Pelejero, C., Canals, M., Sierro, F.J., Flores, J.A., Shackleton, N.J., 968 1999. Dansgaard-Oeschger and Heinrich event imprints in Alboran Sea paleotemperatures. 969 Paleoceanography 14(6), 698-705.

970

971 Cacho, I., Grimalt, J.O., Sierro, F.J., Shackleton, N.J., Canals, M., 2000. Evidence for enhanced 972 Mediterranean thermohaline circulation during rapid climatic coolings. Earth and Planetary 973 Science Letters 183(3-4), 417-429. 
975 Cacho, I., Shackleton, N., Elderfield, H., Sierro, F.J., Grimalt, J.O., 2006. Glacial rapid

976 variability in deep-water temperature and $\delta 180$ from the Western Mediterranean Sea. Quaternary 977 Science Reviews 25 (23-24), 3294-3311.

978

979 Candela, J., Winant, C., Bryden, H., 1989. Meteorologically forced subinertial flows through the 980 Strait of Gibraltar. Journal of Geophysical Research 94 (C9), 12667-12679.

982 Cayre, O., Lancelot, Y., Vincent, E., 1999. Paleoceanographic reconstructions from planktonic 983 foraminifera off the Iberian Margin: Temperature, salinity, and Heinrich events.

984 Paleoceanography 14(3), 384-396.

985

986 Clement, A.C., Peterson, L., 2008. Mechanisms of abrupt climate change of the last glacial 987 period. Reviews of Geophysics 46, RG4002, 1-39.

988

989 Combourieu-Nebout, N., Paterne, M., Turon, J.L., Siani, G., 1998. A high resolution record of 990 the last deglaciation in the central Mediterranean Sea : palaeovegetation and palaeohydrological 991 evolution. Quaternary Science Reviews 17, 303-317.

992

993 Combourieu-Nebout, N., Turon, J.L., Zahn, R., Capotondi, L., Londeix, L., Pahnke, K., 2002.

994 Enhanced aridity and atmospheric high-pressure stability over the western Mediterranean during 995 the North Atlantic cold events of the past 50 k.y. Geology 30, 863-866. 
997 Craig, H., Gordon, L.I., 1965. Stable isotopes in Oceanographic Studies and Paleotemperatures.

998 (Tongiorgi eds, CNR Pisa, 1965).

999

1000 Dale, B., 1977. New observations on Peridinium faeroense Paulsen (1905), and classification of

1001 small orthoperidinoid dinoflagellates. British Phycological Journal 12, 241-253.

1002

1003 Dale, B., 1985. Dinoflagellate cyst analysis of Upper Quaternary sediments in core GIK 15530-4

1004 from the Skagerrak. Norsk geologisk tidsskrift 65, 97-102.

1005

1006 Dale, B., Thorsen, T.A., Fjellså, A., 1999. Dinoflagellate cysts as indicator of cultural

1007 eutrophication in the Oslofjord, Norway. Estuarine, Coastal and Shelf Science 48, 371-382.

1008

1009 Daniau, A.L., Sánchez-Goñi, M.F., Beaufort, L., Laggoun-Défarge, F., Loutre, M.F., Duprat, J.,

1010 2007. Dansgaard-Oeschger climatic variability revealed by fire emissions in south-western Iberia.

1011 Quat. Sci. Rev. 26, 1369-1383.

1012

1013 Dansgaard, W., Johnsen, S.J., Clausen, H.B., Dahl-Jensen, D., Gundestrup, N.S., Hammer, C.U.,

1014 Hvidberg, C.S., Steffenson, J.P., Sveinbjörnsdottir, A.E., Jouzel, J., Bond, G., 1993. Evidence for

1015 general instability of past climate from a 250-kyr ice-core record. Nature 364, 218-220.

1016

1017 de Abreu, L., Shackleton, N.J., Schönfeld, J., Hall, M., Chapman, M., 2003. Millennial-scale

1018 oceanic climate variability off the western Iberian margin during the last two glacial periods.

1019 Marine Geology 196, 1-20.

1020 
1021 Denton, G.H., Alley, R.B., Comer, G.C., Broecker, W.S., 2005. The role of seasonality in abrupt

1022 climate change. Quaternary Science Reviews 24 (10-11), 1159-1182.

1023

1024

de Vernal, A., Rochon, A., Turon, J.L., Matthiessen, J., 1997. Organic-walled dinoflagellate

1025 cysts: palynological tracers of sea-surface conditions in middle to high latitude marine environments. GEOBIOS 30, 905-920.

1027

1028

de Vernal, A., Henry, M., Bilodeau, G., 1999. Technique de préparation et d'analyse en

1029 micropaléontologie. Les Cahiers du GEOTOP vol. 3, Université du Québec à Montréal,

1030 Montréal, Canada.

1031

1032 de Vernal, A., Henry, M., Matthiessen, J., Mudie, P.J., Rochon, A., Boessenkool, K.P., Eynaud,

1033 F., Grøsfjeld, K., Guiot, J., Hamel, D., Harland, R., Head, M.J., Kunz-Pirrung, M., Levac, E.,

1034 Loucheur, V., Peyron, O., Pospelova, V., Radi, T., Turon, J.L., Voronina, E., 2001.

1035 Dinoflagellate cyst assemblages as tracers of sea-surface conditions in the Northern North

1036 Atlantic, Arctic and sub-Arctic seas: The new ' $n=677$ ' data base and its application for

1037 quantitative palaeoceanographic reconstruction. Journal of Quaternary Sciences 16, 681-698.

1038

1039 de Vernal, A., Eynaud, F., Henry, M., Hillaire-Marcel, C., Londeix, L., Mangin, S., Matthiessen,

1040 J., Marret, F., Radi, T., Rochon, A., Solignac, S., Turon, J.L., 2005. Reconstruction of sea-surface

1041 conditions at middle to high latitudes of the Northern Hemisphere during the last glacial

1042 maximum (LGM) based on dinoflagellate cyst assemblages. Quat. Sci. Rev. 24, 897-924. 
49

1044 de Vernal, A., Marret, F., 2007. Organic-walled dinoflagellates : tracers of sea-surface

1045 conditions, In Hillaire-Marcel and de Vernal (eds.) Proxies in Late Cenozoic Paleoceanography,

1046 Elsevier, 371-408.

1047

1048 Devillers, R., de Vernal, A., 2000. Distribution of dinoflagellate cysts in surface sediments of the

1049 northern North Atlantic in relation to nutrient content and productivity in surface waters. Marine

1050 Geology 166, 103-124.

1051

1052 Dodge, J.D., Harland, R., 1991. The distribution of planktonic dinoflagellates and their cysts in

1053 the eastern and north-eastern Atlantic Ocean. New Phytol. 118, 593-603.

1054

1055 Duplessy, J.C., Labeyrie, L., Juillet-Leclerc, A., Maitre, F., Duprat, J., Sarnthein, M., 1991.

1056 Surface salinity reconstruction of the North Atlantic Ocean during the last glacial maximum.

1057 Oceanologica Acta 14, 311-324.

1058

1059 Elliot, M., Labeyrie, L., Duplessy, J.C., 2002. Changes in North Atlantic deep-water formation 1060 associated with the Dansgaard-Oeschger temperature oscillations (60-10 ka). Quat. Sci. Rev. 21, 1061 1153-1165.

1062

1063 Epstein, S., Buchsbaum, R., Lowenstam, H.A., Urey, H.C., 1953. Revised carbonate-water

1064 isotopic temperature scale. Geological Society of America Bulletin 64, 1315-1325.

1065 
1066 Eynaud, F., 1999. Kystes de Dinoflagellés et Evolution paléoclimatique et paléohydrologique de

1067 l'Atlantique Nord au cours du Dernier Cycle Climatique du Quaternaire. PhD, Bordeaux 1 Univ., $1068291 \mathrm{pp}$.

1069

1070 Eynaud, F., Turon, J.L., Sánchez-Goñi, M.F., Gendreau, S., 2000. Dinoflagellate cyst evidence of

1071 "Heinrich-like events" off Portugal during the marine isotopic stage 5. Mar. Micropal. 40, 9-21.

1072

1073 Eynaud, F., Turon, J.L., Duprat, J., 2004. Comparison of the Holocene and Eemian

1074 palaeoenvironments in the South-Icelandic basin: dinoflagellate cysts as proxies for the North

1075 Atlantic surface circulation. Review of Paleobotany and Palynology 128, 55-79.

1076

1077 Eynaud, F., de Abreu, L., Voelker, A., Schönfeld, J., Salgueiro, E., Turon, J.L., Penaud, A.,

1078 Toucanne, S., Naughton, F., Sánchez-Goñi, M.F., Malaizé, B., Cacho, I., 2009. Position of the

1079 Polar Front along the western Iberian margin during key cold episodes of the last $45 \mathrm{ka}$.

1080 Geochem. Geophys. Geosyst. 10, Q07U05, doi:10.1029/2009GC002398.

1081

1082 Eynaud, F., Malaizé, B., de Vernal, A., Zaragosi, S., Pujol, C., Turon, J.L., Cortijo, E., Penaud,

1083 A., Toucanne, S., Grousset, F.E., submitted for publication. Late Pleistocene (35-10 ka) salinity 1084 changes along the Celtic margin, eastern North Atlantic.

1085

1086 Fensome, R.A., MacRae, R.A., Williams, G.L., 1998. DINOFLAJ. Geological Survey of Canada 1087 Open File, 3653. 
1089 Fensome, R.A., Williams, G.L., 2004. The Lentin and Williams index of fossil dinoflagellates, 10902004 edition. AASP Foundation Contributions Series, 42, 909 pp.

1091

1092 Fiúza, A.F.G., 1984. Hidrologia e dinâmica das águas costeiras de Portugal. Ph.D. thesis, Univ. 1093 of Lisbon, Lisbon.

1094

1095 Fiúza, A.F.G., Hamann, M., Ambar, I., Del Rio, G.D., González, N., Cabanas, J.M., 1998. Water 1096 masses and their circulation off western Iberia during May 1993. Deep Sea Res. I 45, 1127-1160. 1097

1098 Fletcher, W.J., Sánchez-Goñi M.F., 2008. Orbital- and sub-orbital scale climate impacts on 1099 vegetation of the western Mediterranean basin over the last 48,000 yr. Quat. Res. 70, 451-464. 1100

1101 Frigola, J., Moreno, A., Cacho, I., Canals, M., Sierro, F.J., Flores, J.A., Grimalt, J.O., 2008.

1102 Evidence of abrupt changes in Western Mediterranean Deep Water circulation during the last 50 1103 kyr: A high-resolution marine record from the Balearic Sea. Quaternary International 181 (1), 881104104.

1105

1106 Garcia-Gorriz, E., Carr, M.E., 1999. The climatological annual cycle of satellite-derived 1107 phytoplankton pigments in the Alboran Sea. Geophysical Research Letters 26 (19), 2985-2988. 1108

1109 Garcia-Lafuente, J., Cano, N., Vargas, M., Rubin, J.P., Hernandez-Guerra, A., 1998. Evolution of 1110 the Alboran Sea hydrographic structures during July 1993. Deep Sea Research I 45, 39-65. 
1112 Garcia-Lafuente, J., Delgado, J., Vargas, J.M., Vargas, M., Plaza, F., Sarhan, T., 2002. Low

1113 frequency variability of the exchanged flows through the Strait of Gibraltar during CANIGO.

1114 Deep-Sea Research II 49 (19), 4051-4067.

1115

1116 Garcia-Soto, C., Pingree, R.D., Valdés, L., 2002. Navidad development in the southern Bay of

1117 Biscay: Climate change and swoddy structure from remote sensing and in situ measurements. J.

1118 Geophys. Res. 107 (C8), 3118.

1119

1120 Grootes, P.M., Stuiver, M., White, J.W.C., Johnsen, S., Jouzel, J., 1993. Comparison of oxygen

1121 isotope records from the GISP2 and GRIP Greenland ice cores. Nature 366, 552-554.

1122

1123 Grøsfjeld, K., Funder, S., Seidenkrantz, M.S., Glaister, C., 2006. Last Interglacial marine

1124 environments in the White Sea region, north-western Russia. Boreas 35(3), 493-520.

1125

1126 Guiot, J., Goeury, C., 1996. PPPbase, a software for statistical analysis of paleoecological data.

1127 Dendrochronologia 14, 295-300.

1128

1129 Guiot, J., de Vernal, A., 2007. Transfer functions: methods for quantitative paleoceanography

1130 based on microfossils. In Hillaire-Marcel and de Vernal (eds.). Proxies in Late Cenozoic

1131 Paleoceanography, Elsevier, 523-563.

1132

1133 Harland, R., 1983. Distribution maps of Recent dinoflagellate cysts in bottom sediments from the

1134 North Atlantic Ocean and adjacent seas. Paleontology 26(2), 321-387.

1135 
1136 Harland, R., Nordberg, K., Filipsson, H.L., 2004a. A high-resolution dinoflagellate cyst record

1137 from latest Holocene sediments in Koljö Fjord, Sweden. Review of Palaeobotany and Palynology

$1138 \quad 128,119-141$.

1139

1140 Harland, R., Nordberg, K., Filipsson, H.L., 2004b. The seasonal occurrence of dinoflagellate

1141 cysts in surface sediments from Koljö Fjord, west coast of Sweden - a note. Review of

1142 Palaeobotany and Palynology 128, 107-117.

1143

1144 Hayes, A., Kucera, M., Kallel, N., Sbaffi L., Rohling, E. J., 2005. Glacial Mediterranean sea

1145 surface temperatures based on planktonic foraminiferal assemblages. Quaternary Science

1146 Reviews 24, 999-1 016.

1147

1148 Head, M.J., 1996. Modern dinoflagellate cysts and their biological affinities. In "Palynology:

1149 principles and Applications. Chapter 30." (Jansonius, J., and McGregor, D.C., editors), AASP

$1150 \quad$ Foundation, 1 197-1 248.

1151

1152 Hemming, S.R., 2004. Heinrich events: Massive late Pleistocene detritus layers of the North

1153 Atlantic and their global climate imprint, Rev. Geophys., 42, RG1005,

1154 doi:10.1029/2003RG000128.

1155

1156 Hill, A.E., Mitchelson-Jacob, E.G., 1993. Observations of a poleward-flowing saline core on the 1157 continental slope west of Scotland. Deep-Sea Research 40, 1521-1527. 
1159 Holzwarth, U., Meggers, H., Esper, O., Kuhlmann, H., Freudenthal, T., Hensen, C., Zonneveld,

1160 K.A.F., 2010. NW African climate variations during the last 47,000 years: Evidence from

1161 organic-walled dinoflagellate cysts. Palaeogeography, Palaeoclimatology, Palaeoecology 291 (3$11624), 443-455$.

1163

1164 Hurrell, J.W., 1995. Decadal trends in the North Atlantic Oscillation: Regional temperatures and 1165 precipitation. Science 269, 676-679.

1166

1167 Iorga, M., Lozier, M.S., 1999. Signature of the Mediterranean outflow from a North Atlantic

1168 climatology: 1. Salinity and density field. J. Geophys. Res. 104 (C11), 25 985-26 009.

1169

1170 Johnsen, S.J., Clausen, H.B., Dansgaard, W., Fuhrer, K., Gundestrup, N., Hammer, C.U., Iversen,

1171 P., Jouzel, J., Stauffer, B., Steffensen, J.P., 1992. Irregular glacial interstadial recorded in a new

1172 Greenland ice core. Nature 359(6393), 311-313.

1173

1174 Johnson, R.G., 1997. Ice age initiation by an ocean-atmospheric circulation change in the

1175 Labrador Sea. Earth and Planetary Science Letters 148 (1-2), 367-379.

1176

1177 Kageyama, M., Mignot, J., Swingedouw, D., Marzin, C., Alkama, R., Marti, O., 2009. Glacial

1178 climate sensitivity to different states of the Atlantic Meridional Overturning Circulation: results

1179 from the IPSL model. Climate of the Past 5, 551-570.

1180

1181 Keigwin, L. D., Boyle, E.A., 1999. Surface and deep ocean variability in the northern Sargasso

1182 Sea during marine isotope stage 3. Paleoceanography 14(2), 164-170. 
1184 Kodrans-Nsiah, M., de Lange, G.J., Zonneveld, K.A.F., 2008. A natural exposure experiment on

1185 short-term species-selective aerobic degradation of dinoflagellate cysts. Review of Palaeobotany 1186 and Palynology 152 (1-2), 32-39.

1187

1188 Kucera, M., Weinelt, M., Kiefer, T., Pflaumann, U., Hayes, A., Weinelt, M., Chen, M.T., Mix,

1189 A.C., Barrows, T.T., Cortijo, E., Duprat, J., Juggins, S., Waelbroeck, C., 2005. Reconstruction of 1190 sea-surface temperatures from assemblages of planktonic foraminifera: Multi-technique approach 1191 based on geographically constrained calibration data sets and its application to glacial Atlantic 1192 and Pacific Oceans. Quaternary Science Reviews 24(7-9), Special Issue, 951-998.

1194 Kucera, M., 2007. Planktonic foraminifera as tracers of past oceanic environments. In: Hillaire-

1195 Marcel, C. and de Vernal, A. (eds): Developments in Marine Geology, Volume 1, Proxies in late

1196 Cenozoic Paleoceanography, Elsevier, 213-262.

1197

1198 Lebreiro, S.M., Moreno, J.C., Abrantes, F.F., Pflaumann, U., 1997. Productivity and

1199 paleoceanographic implications on the Tore Seamount (Iberian Margin) during the last 225 kyr:

1200 Foraminiferal evidence. Paleoceanography 12(5), 718-727.

1201

1202 LeGrande, A., Schmidt, G.A., 2006. Global gridded data set of the oxygen isotopic composition

1203 in seawater. Geophysical Research Letters 33, L12604. doi:10.1029/2006GL026011.

1204

1205 Lewis, J., 1988. Cysts and sediments: Gonyaulax polyedra (Lingulodinium machaerophorum) in 1206 Loch Ceran. Journal of the Marine Biology Association of the United Kingdom 68, 701-714. 
1208 Macias, D., Navarro, G., Echevarria, F., Garcia, C.M., Cueto, J.L., 2007. Phytoplankton

1209 distribution in the north-western Alboran Sea and meteorological forcing: a remote sensing study.

1210 Journal of Marine Research 64 (4), 523-543.

1211

1212 Macias, D., Bruno, M., Echevarria, F., Vazquez, A., Garcia, C.M., 2008. Meteorologically-

1213 induced mesoscale variability of the North-western Alboran Sea (southern Spain) and related

1214 biological patterns. Estuarine, Coastal and Shelf Science 78, 250-266.

1215

1216 Malaizé, B., Caley, T., 2009. Sea surface salinity reconstructions as seen with foraminifera shells:

1217 Methods and cases studies. European Physical journal 167, Special Topics, 179-190.

1218

1219 Mangin, S., 2002. Distribution actuelle des kystes de dinoflagellés en Méditerranée occidentale et 1220 application aux fonctions de transfert, vol. 1. Memoir of DEA, University of Bordeaux, 34 pp.

1222 MARGO Project Members, 2009. Constraints on the magnitude and patterns of ocean cooling at 1223 the Last Glacial Maximum. Nature Geoscience 2, 127-132.

1225 Marret, F., 1994. Distribution of dinoflagellate cysts in recent marine sediments from the east

1226 Equatorial Atlantic (Gulf of Guinea). Review of Palaeobotany and Palynology 84, 1-22.

1228 Marret, F., Turon, J.L., 1994. Paleohydrology and paleoclimatology off Northwest Africa during 1229 the last glacial-interglacial transition and the Holocene : Palynological evidences. Marine 1230 Geology 118, 107-117. 
1232 Marret, F., Zonneveld, K.A.F., 2003. Atlas of modern organic-walled dinoflagellate cyst

1233 distribution. Review of Palaeobotany and Palynology 125, 1-200.

1234

1235 Marret, F, Eiríksson, J., Knudsen, K.L., Turon, J.L., Scourse, J.D., 2004. Distribution of

1236 dinoflagellate cyst assemblages in surface sediments from the northern and western shelf of

1237 Iceland. Review of Palaeobotany and Palynology 128, 35-53.

1238

1239 Martrat, B., Grimalt, J.O., Lopez-Martinez, C., Cacho, I., Sierro, F.J., Flores, J.A., Zahn, R.,

1240 Canals, M., Curtis, J.H., Hodell, D.A., 2004. Abrupt temperature changes in the western

1241 Mediterranean over the past 250,000 years. Science 306, 1762-1765.

1242

1243 Martrat, B., Grimalt, J.O., Shackleton, N.J., de Abreu, L., Hutterli, M.A., Stocker, T.F., 2007.

1244 Four climate cycles of recurring deep and surface water destabilizations on the Iberian Margin.

1245 Science 317, 502-507.

1246

1247 Maslin, M.A., Shackleton, N. J., Pflaumann, U., 1995. Surface water temperature, salinity and 1248 density changes in the northeast Atlantic during the last 45,000 years: Heinrich events, deep1249 water formation and climate rebounds. Paleoceanography 10(3), 527-544.

1251 Matsuzaki, K.M.R., Eynaud, F., Malaizé, B., Grousset, F.E., Tisserand, A., Rossignol, L.,

1252 Charlier, K., Jullien, E., 2011. Paleoceanography of the Mauritanian margin during the last two 1253 climatic cycles: from planktonic foraminifera to African climate dynamic. Marine

1254 Micropaleontology, doi:10.1016/j.marmicro.2011.01.004. 
1256 Matthiessen, J., 1995. Distribution patterns of dinoflagellate cysts and other organic-walled

1257 microfossils in recent Norwegian-Greenland Sea sediments. Mar. Micropal. 24, 307-334.

1258

1259 Mauritzen, C., 1996. Production of dense overflow waters feeding the North Atlantic across the

1260 Greenland-Scotland Ridge. Part 1: Evidence for a revised circulation scheme. Deep-Sea Research 1261 I 43(6), 769-806.

1262

1263 Meijer, P.Th., Tuenter, E., 2007. The effect of precession-induced changes in the Mediterranean

1264 freshwater budget on circulation at shallow and intermediate depth. Journal of Marine Systems $126568(3-4), 349-365$.

1266

1267 Mertens, K., Ribeiro, S., et al., 2009. Process length variation in cysts of a dinoflagellate,

1268 Lingulodinium machaerophorum, in surface sediments: Investigating its potential as salinity 1269 proxy. Marine Micropaleontology 70, 54-69.

1270

1271 Moreno, A., Cacho, I., Canals, M., Prins, M.A., Sánchez-Goñi, M.F., Grimalt, J.O., Weltje, G.J., 1272 2002. Saharan dust transport and high-latitude glacial climatic variability: The Alboran Sea 1273 record. Quaternary Research 58 (3), 318-328.

1275 Moreno, A., Cacho, I., Canals, M., Grimalt, J.O., Sanchez-Vidal, A., 2004. Millennial-scale 1276 variability in the productivity signal from the Alboran Sea record, Western Mediterranean Sea.

1277 Palaeogeography, Palaeoclimatology, Palaeoecology 211 (3-4), 205-219. 
1279 Moreno, A., Cacho, I., Canals, M., Grimalt, J.O., Sánchez-Goñi, M.F., Shackleton, N.J., Sierro, 1280 F.J., 2005. Links between marine and atmospheric processes oscillating on a millennial time1281 scale. A multiproxy study of the last 50,000 yr from the Alboran Sea (Western Mediterranean 1282 Sea). Quaternary Science Reviews 24, 1623-1636.

1283

1284 Morzadec-Kerfourn, M.T., 1988. Distribution des kystes de dinoflagellés dans les sédiments

1285 Pléistocènes de la marge Guinéenne de l'Afrique (Equamarge I, 1983) = Distribution of 1286 dinoflagellate cysts in Pleistocene sediments of the Guinean margin of Africa, Equamarge I, 1287 1983. Palaeogeography, palaeoclimatology, palaeoecology 65 (3-4), 201-216.

1288

1289 Mudie, P.J., 1992. Circum-Arctic Quaternary and Neogene marine palynofloras: paleoecology 1290 and statistical analysis. In Head, M.J., and Wrenn, J.H. (Eds.), Neogene and Quaternary

1291 Dinoflagellate Cysts and Acritarchs. Am. Assoc. Stratigr. Palynol. Foundation, 347-390.

1292

1293 Mudie, P.J., Rochon, A., Aksu, A.E., Gillespie, H., 2002. Dinoflagellate cysts, freshwater algae 1294 and fungal spores as salinity indicators in Late Quaternary cores from Marmara and Black seas. 1295 Marine Geology 190, 203-231.

1296

1297 Mudie, P.J., Rochon, A., Aksu, A.E., Gillespie, H., 2004. Late glacial, Holocene and modern 1298 dinoflagellate cyst assemblages in the Aegean-Marmara-Black Sea corridor: statistical analysis 1299 and re-interpretation of the early Holocene Noah's Flood hypothesis. Review of Palaeobotany 1300 and Palynology 128, 143-167. 
60

1302 Naughton, F., Sánchez-Goñi, M.F., Kageyama, M., Bard, E., Duprat, J., Cortijo, E., Desprat, S.,

1303 Malaizé, B., Joly, C., Rostek, F., 2009. Wet to dry climatic trend in north western Iberia within

1304 Heinrich events. Earth Planet. Sci. Lett. 284(3-4), 329-342.

1305

1306 O'Neill-Baringer, M., Price, J.F., 1999. A review of the physical oceanography of the

1307 Mediterranean outflow. Marine Geology 155, 63-82.

1308

1309 Osborn, T.J., Briffa, K.R., Tett, S.F.B., Jones, P.D., Trigo, R.M., 1999. Evaluation of the North

1310 Atlantic Oscillation as simulated by a coupled climate model. Clim. Dyn. 15, 685-702.

1311

1312 Ostlund, H.G., Craig, H., Broecker, W.S., Spenser, D. (Eds.),1987. GEOSECS Atlantic, Pacific

1313 and Indian Ocean Expeditions, vol. 7, Shorebased Data and Graphics, Int. Decade of Ocean

1314 Explor. Natl. Science Found., Washington D.C.

1315

1316 Pailler, D., Bard, E., 2002. High frequency palaeoceanographic changes during the past 140000

1317 yr recorded by the organic matter in sediments of the Iberian Margin. Palaeogeography,

1318 Palaeoclimatology, Palaeoecology 181(4), 431-452.

1319

1320 Peliz, A., Dubert, J., Santos, A., Oliveira, P., Le Cann, B., 2005. Winter upper ocean circulation

1321 in the Western Iberian Basin-Fronts, eddies and poleward flows: An overview. Deep Sea Res. I

$132252,621-646$.

1323 
61

1324 Penaud, A., Eynaud, F., Turon, J.L., Zaragosi, S., Marret, F., Bourillet, J.F., 2008. Interglacial

1325 variability (MIS 5 and MIS 7) and dinoflagellate cyst assemblages in the Bay of Biscay (North

1326 Atlantic). Marine Micropaleontology 68, 136-155.

1327

1328 Penaud, A., Eynaud, F., Turon, J.L., Zaragosi, S., Malaizé, B., Toucanne, S., Bourillet, J.F., 2009.

1329 What forced the collapse of European ice sheets during the last two glacial periods (150 ka B.P.

1330 and 18 ka cal B.P.)? Palynological evidence. Palaeogeography, Palaeoclimatology,

1331 Palaeoecology 281, 66-78.

1332

1333 Penaud, A., Eynaud, F., Turon, J.L., Blamart, D., Rossignol, L., Marret, F., Lopez-Martinez, C.,

1334 Grimalt, J.O., Malaizé, B., Charlier, K., 2010. Contrasting Heinrich Events 1, 2, and LGM

1335 conditions off Morocco: Paleoceanographical evidences of warmer LGM and colder HE 1.

1336 Quaternary Science Reviews 29 (15-16), 1923-1939.

1337

1338 Pérez-Folgado, M., Sierro, F.J., Flores, J.A., Cacho, I., Grimalt, J.O., Zahn, R., Shackleton, N.J.,

1339 2003. Western Mediterranean planktonic foraminifera events and millennial climatic variability

1340 during the last 70 kyr. Mar. Micropaleontol. 48, 49-70.

1341

1342 Pflaumann, U., Duprat, J., Pujol, C., Labeyrie, L.D., 1996. SIMMAX: a modern analogue

1343 technique to deduce Atlantic sea surface temperatures from planktonic foraminifera in deep-sea

1344 sediments. Paleoceanography 11(1), 15-35.

1345 
62

1346 Raine, R., White, M., Dodge, J.D., 2002. The summer distribution of net plankton dinoflagellates

1347 and their relation to water movements in the NE Atlantic Ocean, west of Ireland. Journal of

1348 Plankton Research 24, 1 131-1 147.

1349

1350 Reid, P.C., 1972. Dinoflagellate cyst distribution around the British Isles. J. Mar. Ass. U.K. 52,

$1351939-944$.

1352

1353 Reid, P.C., 1974. Gonyaulacacean dinoflagellate cysts from the British Isles. Nova Hedwigia 25, $1354 \quad 579-637$.

1355

1356 Relvas, P., Peliz, A., Barton, E.D., da Silva, J.C., Dubert, J., Santos, M., Oliveira, P.B., 2007.

1357 Western Iberia Upwelling Ecosystem: An oceanographic overview. Prog. Oceanogr. 74, 149-173.

1358

1359 Roche, D., Paillard, D., Cortijo, E., 2004. Constraints on the duration and freshwater release of

1360 Heinrich event 4 through isotope modelling. Nature 432, 379-382.

1361

1362 Rochon, A., de Vernal, A., Turon, J.L., Matthiessen, J., Head, M.J., 1999. Distribution of Recent

1363 Dinoflagellate cysts in surface sediments from the North Atlantic Ocean and adjacent seas in

1364 relation to sea-surface parameters. Am. Assoc. of Stratigr. Palynol., AASP Contr. Ser., 35, 1-152.

1365

1366 Rogerson, M., Rohling, E.J., Weaver, P.P.E., 2006. Promotion of meridional overturning by

1367 Mediterranean-derived salt during the last deglaciation. Paleoceanography 21, PA4101, 1-8. 
1369 Rohling, E.J., Den Dulk, M., Pujol, C., Vergnaud-Grazzini, C., 1995. Abrupt hydrographic

1370 change in the Alboran Sea (western Mediterranean) around 8000 yrs BP. Deep Sea Research I 1371 42(9), 1609-1619.

1372

1373 Rohling, E.J., Abu-Zied, R., Casford, C.S.L., Hayes, A., Hoogakker, B.A.A., 2009. The

1374 Mediterranean Sea: Present and Past. In: Physical Geography of the Mediterranean Basin. Oxford

1375 Regional Environments. Oxford University Press, Oxford, 592 pp.

1376

1377 Roucoux, K.H., Tzedakis, P.C., de Abreu, L., Shackleton, N.J., 2005. The response of NW

1378 Iberian vegetation to North Atlantic climate oscillations during the last 65,000 years. Quat. Sci.

1379 Rev. 24, 1637-1653.

1380

1381 Rouis-Zargouni, I., Turon, J.L., Londeix, L., Essallami, L., Kallel, N., Sicre, M.A., 2010.

1382 Environmental and climatic changes in the central Mediterranean Sea (Siculo-Tunisian Strait)

1383 during the last $30 \mathrm{ka}$ based on dinoflagellate cyst and planktonic foraminifera assemblages.

1384 Palaeogeography, Palaeoclimatology, Palaeoecology 285 (1-2), 17-29.

1385

1386 Ruddiman, W.F., 1977. Late quaternary deposition of ice-rafted sand in the subpolar north

1387 Atlantic (lat $40^{\circ}$ to $65^{\circ} \mathrm{N}$ ). Geol. Soc. Am. Bull. 88, 1813-1827.

1388

1389 Sachs, J. P., Lehman, S.J., 1999. Subtropical North Atlantic temperatures 60,000 to 30,000 years 1390 ago. Science 286, 756-759. 
64

1392 Sánchez, R.F., Relvas, P., 2003. Spring-summer climatological circulation in the upper layer in

1393 the region of Cape St.Vincent, southwest Portugal. ICES J. Mar. Sci. 60, 1232-1250.

1394

1395 Sánchez Goñi, M.F., Eynaud, F., Turon, J.L., Shackleton, N.J., 1999. High resolution

1396 palynological record off the Iberian margin: Direct land-sea correlation for the Last Interglacial

1397 complex. Earth and Planetary Science Letters 171 (1), 123-137.

1398

1399 Sánchez-Goñi, M.F., Turon, J.L., Eynaud, F., Gendreau, S., 2000. European climatic response to

1400 millennial-scale changes in the atmosphere-ocean system during the Last Glacial Period. Quat.

1401 Res. 54, 394-403.

1402

1403 Sánchez-Goñi, M.F., Cacho, I., Turon, J.L., Guiot, J., Sierro, F., Peypouquet, J.P., Grimalt, J.O.,

1404 Shackleton, N.J., 2002. Synchronicity between marine and terrestrial responses to millennial

1405 scale climatic variability during the last glacial period in the Mediterranean region. Climate

1406 Dynamics 19(1), 95-105.

1407

1408 Sánchez-Goñi, M., Landais, A., Fletcher, W., Naughton, F., Desprat, S., Duprat, J., 2008.

1409 Contrasting impacts of Dansgaard-Oeschger events over a western European latitudinal transect

1410 modulated by orbital parameters. Quaternary Science Reviews 27 (11-12), 1136-1151.

1411

1412 Sánchez-Goñi, M., Landais, A., Cacho, I., Duprat, J., Rossignol, L., 2009. Contrasting

1413 intrainterstadial climatic evolution between high and middle North Atlantic latitudes: A close-up

1414 of Greenland Interstadials 8 and 12. Geochem. Geophys. Geosyst. 10, Q04U04,

1415 doi:10.1029/2008GC002369. 
65

1416

1417 Sánchez-Goñi, M.F., Harrison, S.P., 2010. Millennial-scale climate variability and vegetation

1418 changes during the Last Glacial: Concepts and terminology. Quaternary Science Reviews 29 (211419 22), 2823-2827.

1420

1421 Schmidt, G.A., 1999. Error analysis of paleosalinity calculations. Paleoceanography 14, 422-429.

1422

1423 Schulz, M., Berger, W.H., Sarnthein, M., Grootes, P.M., 1999. Amplitude variations of 1470-

1424 year climate oscillations during the last 100,000 years linked to fluctuations of continental ice 1425 mass. Geophysical Research Letters 26 (22), 3385-3388.

1426

1427 Serreze, M.C., Carse, F., Barry, R.G., Rogers, J.C., 1997. Icelandic low cyclone activity:

1428 Climatological features, linkages with the NAO, and relationships with recent changes in the

1429 Northern Hemisphere circulation. Journal of Climate 10, 453-464.

1430

1431 Shackleton, N.J., Hall, M.A., Vincent, E., 2000. Phase relationships between millennial-scale 1432 events 64,000-24,000 years ago. Paleoceanography 15, 565-569.

1433

1434 Shackleton, N.J., Fairbanks, R.G., Chiu, T.C., Parrenin, F., 2004. Absolute calibration of the

1435 Greenland time scale: implications for Antarctic time scales and for d14C. Quaternary Science

1436 Reviews 23, 1513-1522. 
66

1438 Shackleton, N.J., Opdyke, N.D., 1973. Oxygen isotope and palaeomagnetic stratigraphy of

1439 equatorial Pacific core V28-238: oxygen isotope temperatures and ice volumes on a $10^{5}$ and $10^{6}$ 1440 year scale. Quaternary Research 3, 39-55.

1441

1442 Sierro, F.J., Hodell, D.A., Curtis, J.H., Flores, J.A., Reguera, I., Colmenero-Hidalgo, E., Barcena, 1443 M.A., Grimalt, J.O., Cacho, I., Frigola, J., Canals, M., 2005. Impact of iceberg melting on

1444 Mediterranean thermohaline circulation during Heinrich events. Paleoceanography 20, PA2019, $1445 \quad 1-13$

1447 Sprangers, M., Dammers, N., Brinkhuis, H., van Weering, T.C.E., Lotter, A.F., 2004. Modern 1448 organic-walled dinoflagellate cyst distribution offshore NW Iberia; tracing the upwelling system. 1449 Review of Palaeobotany and Palynology 128, 97-106.

1451 Targarona, J., Warnaar, J., Boessenkool, K.P., Brinkhuis, H., Canals, M., 1999. Recent

1452 dinoflagellate cyst distribution in the North Canary Basin, NW Africa. Grana 38, 170-178. 1453

1454 Thouveny, N., Moreno, E., Delanghe, D., Candon, L., Lancelot, Y., Shackleton, N.J., 2000. Rock 1455 magnetic detection of distal ice-rafted debris: Clue for the identification of Heinrich layers on the 1456 Portuguese margin. Earth Planet. Sci. Lett. 180, 61-75.

1458 Tintoré, J., La Violette, P.E., Blade, I., Cruzado, A., 1988. A study of an intense density front in 1459 the eastern Alboran Sea: The Almeria-Oran front. Journal of Physical Oceanography 18, 138414601397. 
67

1462 Toucanne, S., Mulder, T., Schönfeld, J., Hanquiez, V., Gonthier, E., Duprat, J., Cremer, M.,

1463 Zaragosi, S., 2007. Contourites of the Gulf of Cadiz: A high-resolution record of the

1464 paleocirculation of the Mediterranean outflow water during the last 50,000 years.

1465 Palaeogeography, Palaeoclimatology, Palaeoecology 246(2-4), 354-366.

1466

1467 Turon, J. L., 1984. Le palynoplancton dans l'environnement actuel de l'Atlantique Nord-oriental.

1468 Evolution climatique et hydrologique depuis le dernier maximum glaciaire. Mémoires de l'Institut

1469 de Géologie du Bassin d'Aquitaine 17, 313 pp.

1470

1471 Turon, J.L., Londeix, L., 1988. Les asssemblages de kystes de dinoflagellés en Méditerranée

1472 occidentale (Mer d'Alboran): mise en evidence de l'évolution des paléoenvironnement depuis le

1473 dernier maximum glaciaire. Bull. Centres Rech. Explor.-prod. Elf-Aquitaine 12, 313-344.

1474

1475 Turon, J.L., Lézine, A.M., Denèfle, M., 2003. Land-sea correlations for the last glaciation

1476 inferred from a pollen and dinocyst record from the Portuguese margin. Quaternary Research 59, 1477 88-96.

1478

1479 Viúdez, A., Tintoré, J., 1995. Time and space variability in the eastern Alboran Sea from March

1480 to May 1990. J. Geophys. Res. 100(C5), 8 571-8 586.

1481

1482 Voelker, A.H.L., and Workshop Participants, 2002. Global distribution of centennial-scale

1483 records for Marine Isotope Stage (MIS) 3: A database. Quaternary Science Reviews 21 (10),

$1484 \quad 1185-1212$.

1485 
68

1486 Voelker, A.H.L., Lebreiro, S.M., Schönfeld, J., Cacho, I., Erlenkeuser, H., Abrantes, F., 2006.

1487 Mediterranean outflow strengthening during northern hemisphere coolings: A salt source for the 1488 glacial Atlantic? Earth and Planetary Science Letters 245(1-2), 39-55.

1490 Waelbroeck, C., Labeyrie, L., Michel, E., Duplessy, J.C., McManus, J.F., Lambeck, K., Balbon,

1491 E., Labracherie, M., 2002. Sea-level and deep water temperature changes derived from benthic

1492 foraminifera isotopic records. Quaternary Science Reviews 21 (1-3), 295-305.

1493

1494 Wall, D., Dale, B., Lohmann, G.P., Smith, W.K., 1977. The environment and climatic

1495 distribution of dinoflagellate cysts in modern marine sediments from regions in the north and

1496 south Atlantic oceans and adjacent seas. Mar. Micropaleontol. 2, 121-200.

1497

1498 Zaragosi, S., Eynaud, F., Pujol, C., Auffret, G.A., Turon, J.L., Garlan, T., 2001. Initiation of

1499 European deglaciation as recorded in the north-western Bay of Biscay slope environments

1500 (Meriadzek Terrace and Trevelyan Escarpment): a multi-proxy approach. Earth Planet. Sci. Lett.

$1501 \quad 188,493-507$.

1502

1503 Zonneveld, K.A.F., Hoek, R.P., Brinkhuis, H., Willems, H., 2001. Geographical distributions of

1504 organic-walled dinoflagellate cysts in surficial sediments of the Benguela upwelling region and

1505 their relationship to upper ocean conditions. Progress in Oceanography 48, 25-72. 


\section{Figure captions}

1507

1508 Figure 1: Area of interest with major sea-surface features. The studied cores MD95-2043

1509 (Alboran Sea; 36²8.6’ N; 2³7.3'W; 1841 m water depth) and MD95-2042 (Iberian margin;

$151037^{\circ} 48^{\prime} \mathrm{N} ; 10^{\circ} 10^{\prime} \mathrm{W} ; 3146 \mathrm{~m}$ water depth) are located on the large map, depicting also the

1511 bathymetry of the study area and the major surface currents within the Alboran sea; WAG:

1512 Western Alboran Gyre; EAG: Eastern Alboran Gyre; AOF: Almeria-Oran Front; AC: Algerian

1513 Current. The small map on the left shows large scale North-Atlantic currents with: the North

1514 Atlantic Drift (NAD), the Portugal Current (PC) flowing southward from $45^{\circ} \mathrm{N}$ to $30^{\circ} \mathrm{N}$, the

1515 Azores Current (AzC) derived from the southern branch of the Gulf Stream and flowing eastward

1516 to the Gulf of Cadiz at about $35^{\circ} \mathrm{N}$, and the Canary Current (CC) fed by both the AzC and the PC.

1517 Together, these currents form the Eastern Boundary Current of the North Atlantic subtropical

1518 gyre. A Mediterranean analogue of the dinocyst modern database has been located on the map

1519 (M1039). Colors from red to dark blue on the map reflect growing bathymetry towards the 1520 deepest areas.

1521

1522 Figure 2: MD95-2043 (a) and MD95-2042 (b). Core depths are displayed in centimetres along

1523 the vertical axis. The relative abundances of selected dinocyst species are compared with

1524 planktonic $\delta^{18} \mathrm{O}$ data and $\mathrm{U}^{\mathrm{k}}{ }_{37}$-SST (Core MD95-2043: Cacho et al., 1999; Core MD95-2042:

1525 Cayre et al., 1999; Shackleton et al., 2000; Pailler and Bard, 2002), providing the stratigraphical

1526 framework for the two cores. Quaternary dinocyst concentrations are also illustrated. HS:

1527 Heinrich Stadial; GI: Greenland Interstadial. 
1529 Figure 3: MD95-2043 (a) and MD95-2042 (b). Quantitative dinocyst reconstructions (February

1530 and August SST and SSS, 3PBase-940) compared with SST provided by foraminifera (winter,

1531 summer and annual, R-1007) and alkenones ( $\left.\mathrm{U}^{\mathrm{k}^{\prime}}{ }_{37}-\mathrm{SST}\right)$, and SSS provided by calculations

1532 based on planktonic $\delta^{18} \mathrm{O}(\mathrm{G}$. bulloides) and foraminiferal SST estimates (winter and summer, R-

1533 1007). Error bars are shown in the figure for the different reconstructions. HS: Heinrich Stadial;

1534 GI: Greenland Interstadial.

1536 Figure 4: Comparison between cores MD95-2043 and MD95-2042 of a multi-proxy compilation

1537 including: selected dinocyst species, total dinocyst concentrations, February dinocyst (3PBase-

1538 940) and alkenone SST (Cacho et al., 1999; Pailler and Bard, 2002) reconstructions, percentages

1539 of N. pachyderma s. (Cacho et al., 1999; Pérez-Folgado et al., 2003), benthic $\delta^{13} \mathrm{C}$ (Cacho et al.,

1540 2006), and percentages of the Mediterranean forest (Sánchez-Goñi et al., 2000, 2002; Fletcher

1541 and Sánchez-Goñi, 2008). These data are compared with $\delta^{18} \mathrm{O}$ ice core records and the precession

1542 signal (Berger and Loutre, 1991). HS: Heinrich Stadial; GI: Greenland Interstadial.

1543

1544 Figure 5: MD95-2043 (a) and MD95-2042 (b). Estimation of a parameter of seasonality based

1545 on the difference between February and August dinocyst SST reconstructions (3PBase-940),

1546 compared with percentages of the dinocyst species Bitectatodinium tepikiense, the precession

1547 signal (Berger and Loutre, 1991) and planktonic $\delta^{18} \mathrm{O}$ records (G. bulloides). Dinocyst and

1548 alkenone SST records are also represented, as well as modern SST values. HS: Heinrich Stadial;

1549 GI: Greenland Interstadial.

1550

1551 11. Appendices

1552 
1553 Appendix A: MD95-2042 (SW Iberian Margin) and MD95-2043 (Alboran Sea): individual

1554 counts of dinocyst species, total dinocysts counted and total dinocyst concentrations per sample.

1555

1556 Appendix B: MD95-2042 (SW Iberian Margin) and MD95-2043 (Alboran Sea): lists of the five 1557 best analogues found with the transfer function 3PBase-940. The geographical coordinates of 1558 each named analogue can be found on the GEOTOP website

1559 (http://www.geotop.ca/index.php?option=com_content\&task=view\&id=762\&Itemid=226). The

1560 five analogues found by 3PBase-940 have systematically been used for the calculations, the

1561 threshold (Dmin value of 71.72) may then be considered to judge the good reliability of the

1562 reconstructed hydrological parameters. The M1039 analogue, highlighted in the tables in bold, is 1563 a Mediterranean analogue located in Figure 1. 
1565

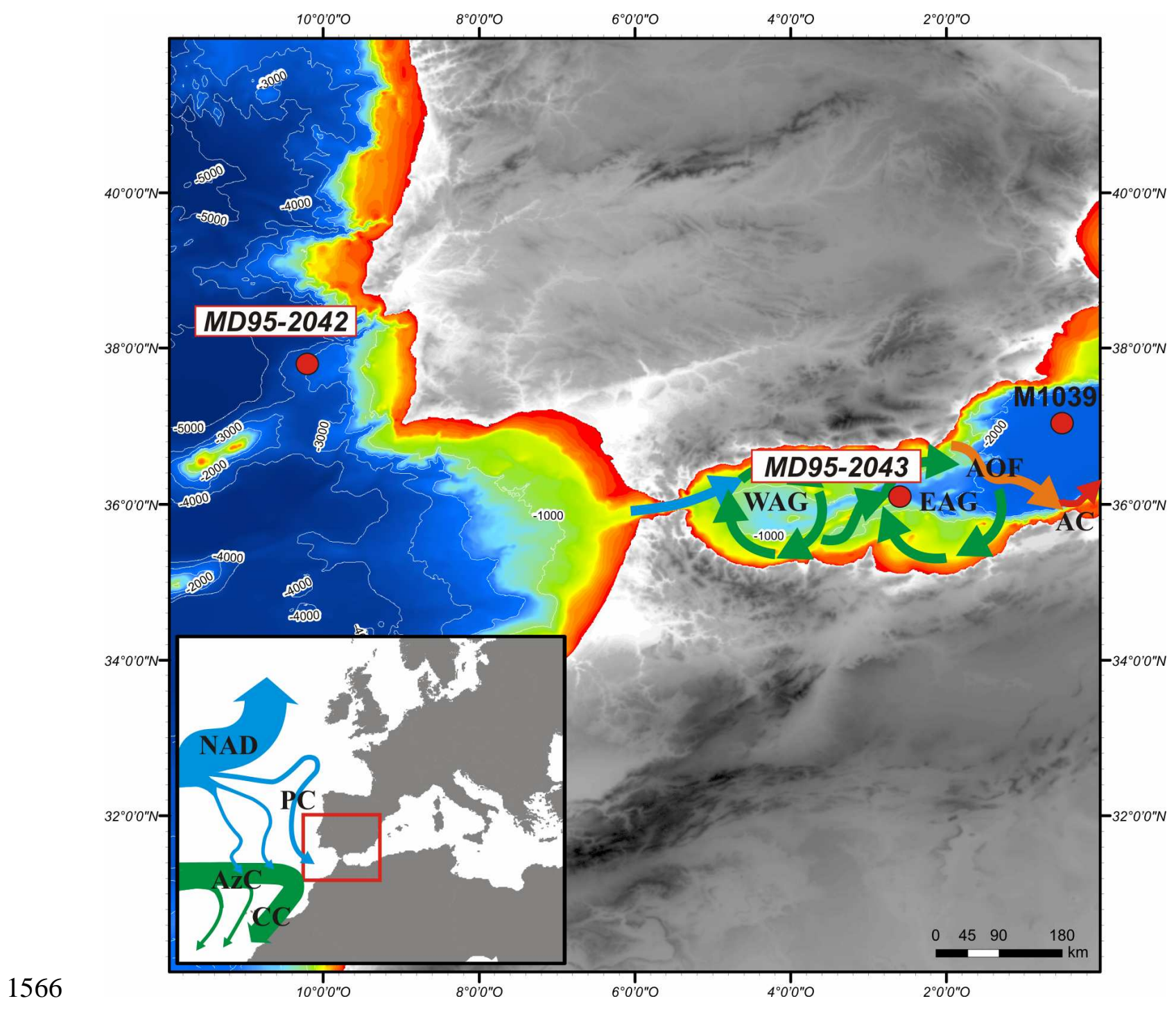

1567

1568

1569 Figure 1 
a) MD95-2043 - Alboran Sea

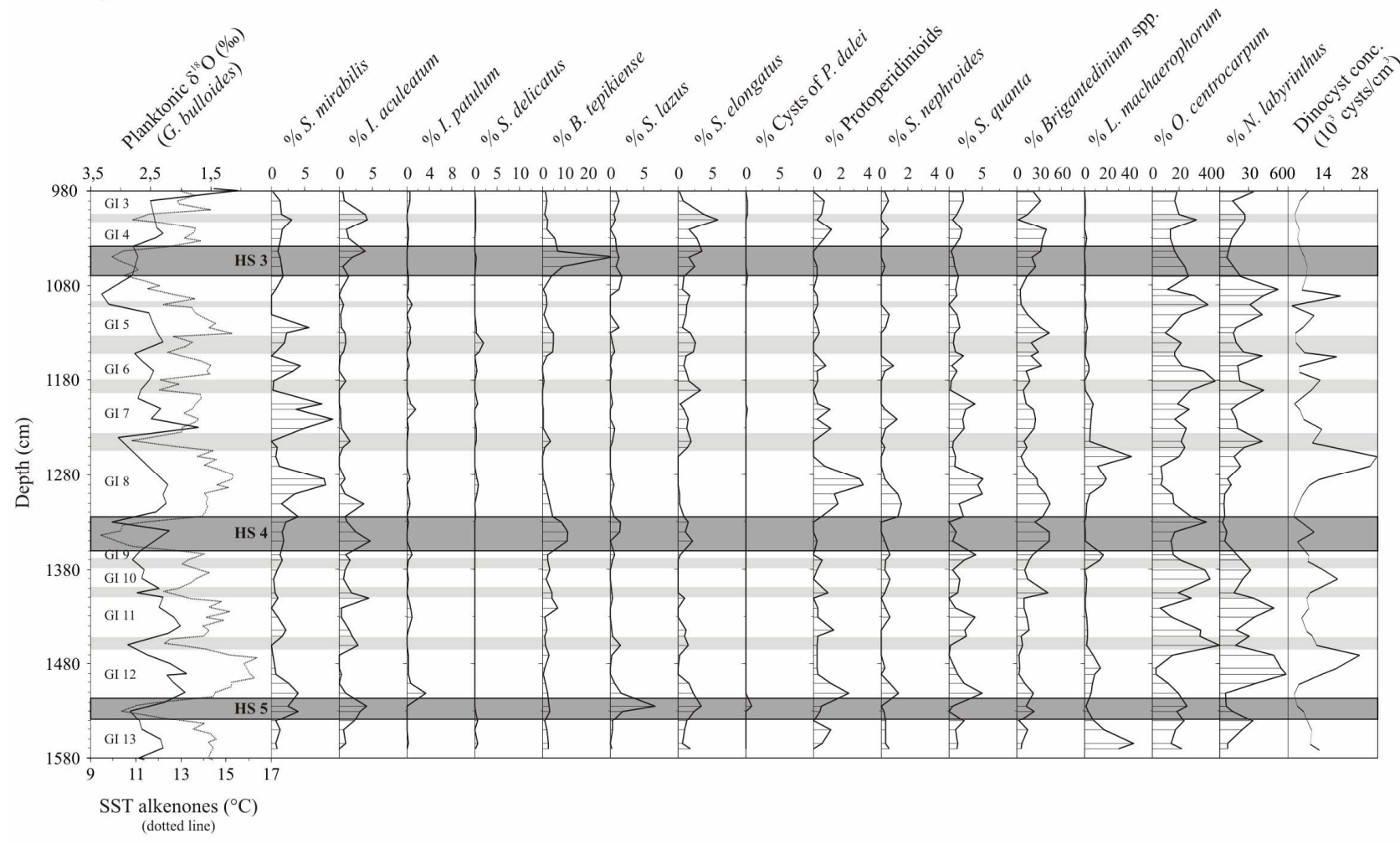

b) MD95-2042 - SW Iberian Margin

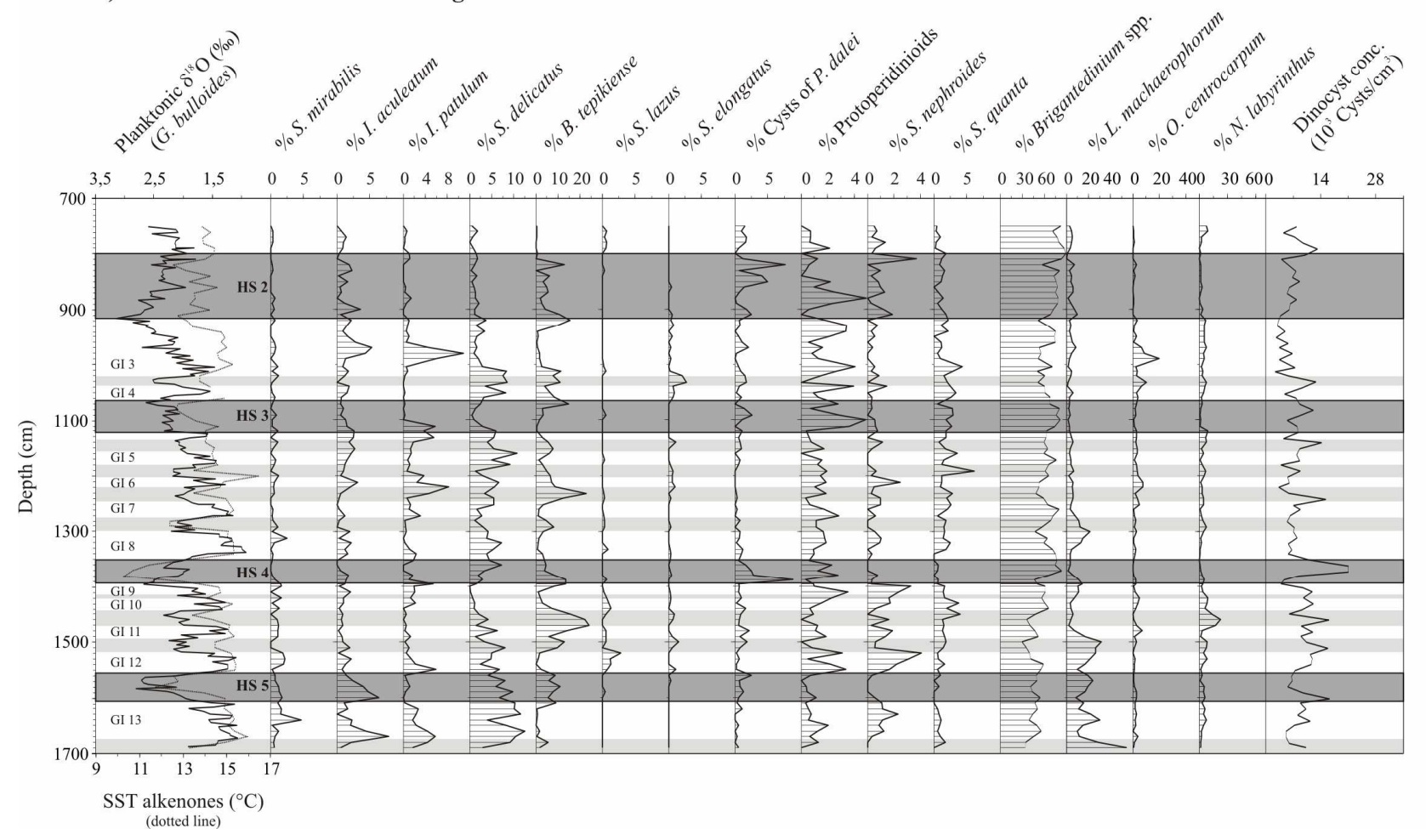

\section{$1571 \quad$ Figure 2}


a) MD95-2043 - Alboran Sea

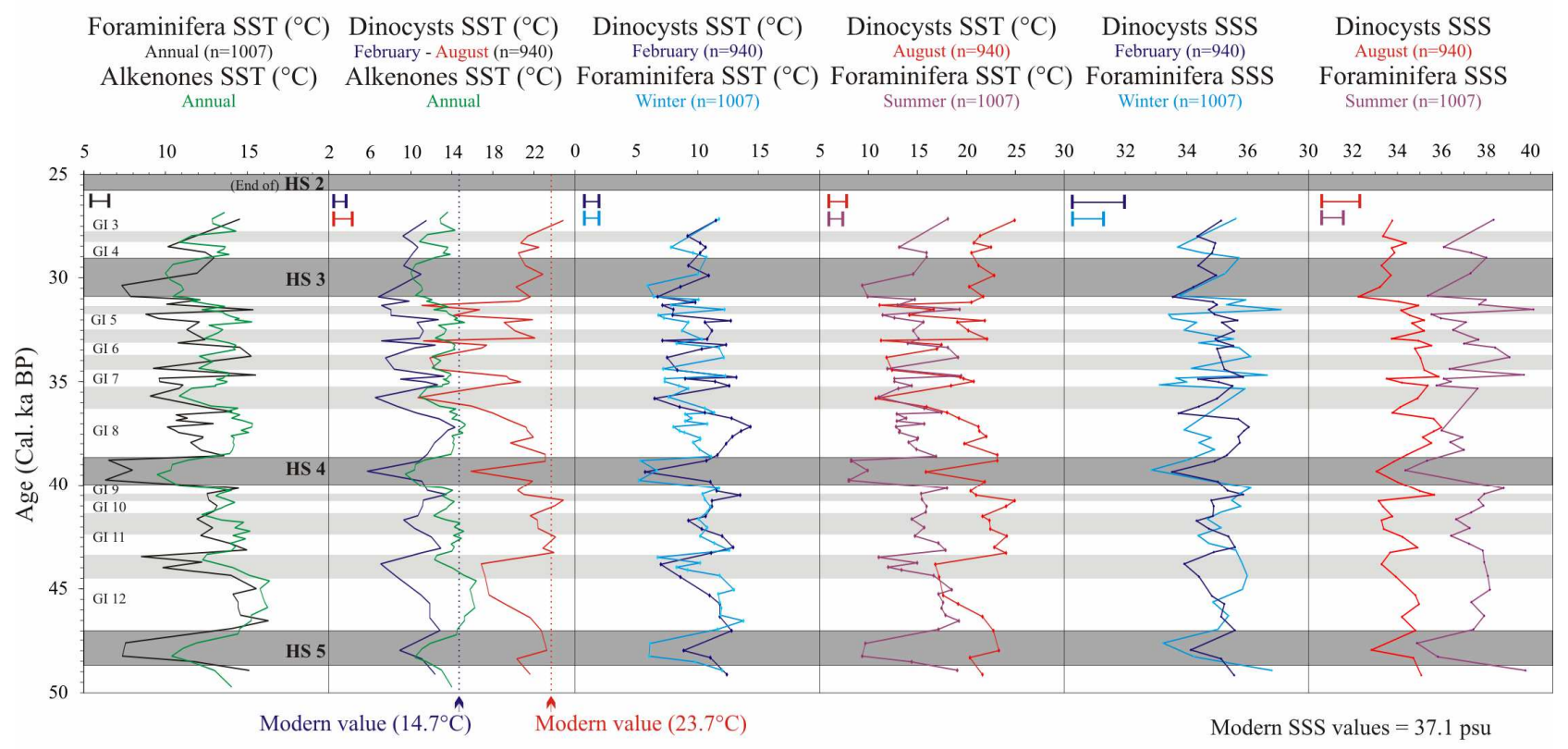

b) MD95-2042 - Iberian Margin

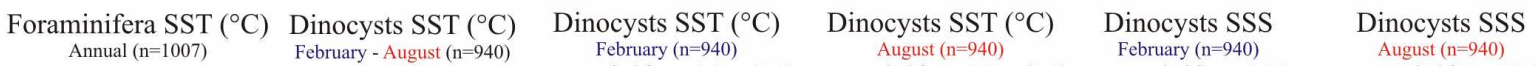

Alkenones SST $\left({ }^{\circ} \mathrm{C}\right) \quad$ Alkenones SST $\left({ }^{\circ} \mathrm{C}\right)$ Foraminifera SST $\left({ }^{\circ} \mathrm{C}\right)$ Foraminifera SST $\left({ }^{\circ} \mathrm{C}\right)$ Foraminifera SSS Foraminifera SSS Annual Annual Winter $(n=1007) \quad$ Summer $(n=1007) \quad$ Winter $(n=1007) \quad$ Summer $(n=1007)$

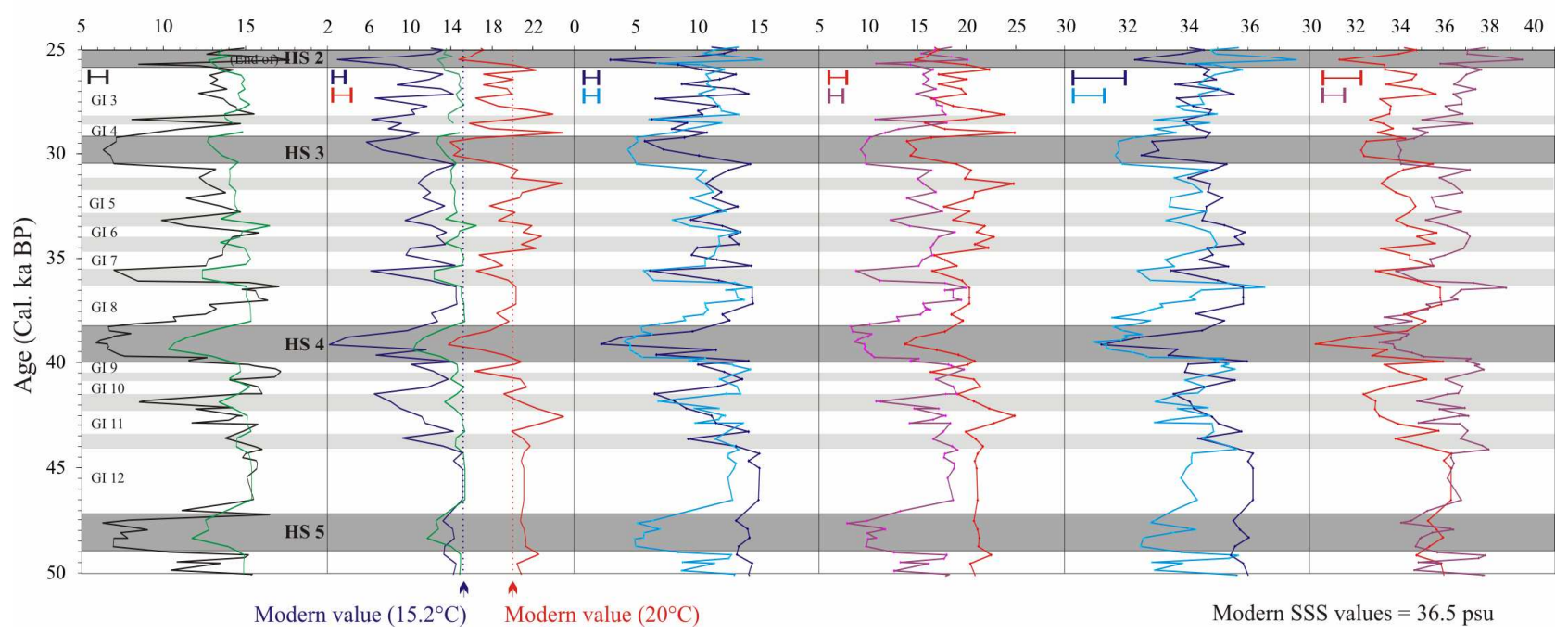

1574

1575 Figure 3 


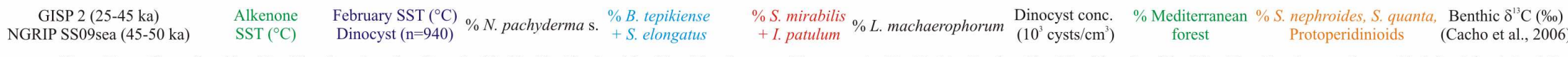
$\begin{array}{lllllllllllllllllllll}-48 & -44 & -40 & 9 & 11 & 13 & 15 & 0 & 4 & 8 & 12 & 0 & 10 & 20 & 30 & 40 & 0 & 10 & 20 & 30 & 0\end{array}$
$\begin{array}{lllllllllllllll}10 & 0 & 10 & 20 & 30 & 40 & 0 & 10 & 20 & 30 & 0 & 10 & 20 & 30 & 40\end{array}$

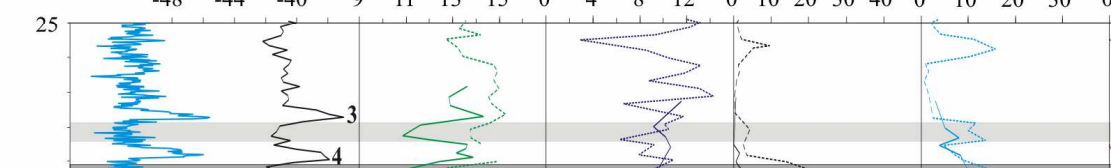

30

HS 3

商

45

HS 3

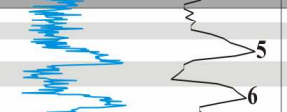

在

$=2$

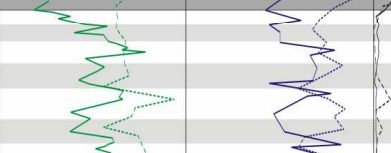

40

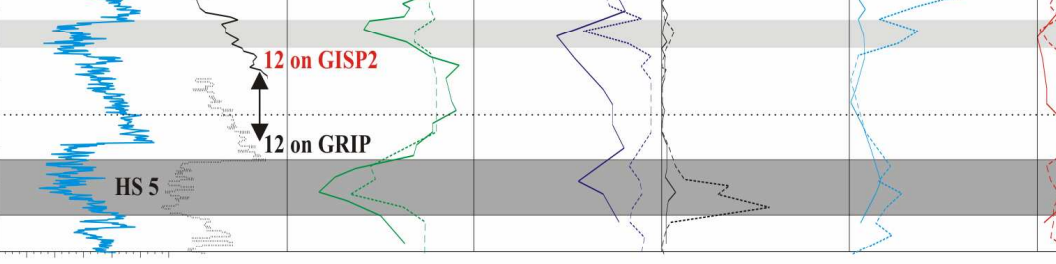

$\begin{array}{llll}50 & & & \\ -48 & -44 & -40 & -36\end{array}$

NGRIP GICC05 $\begin{array}{lllllllllllll}10 & 20 & 30 & 40 & 0 & 10 & 20 & 30 & 0 & 10 & 20 & 30 & 40\end{array}$

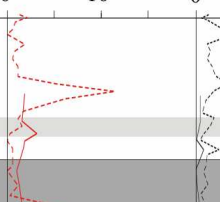
3 
a) MD95-2043 - Alboran Sea

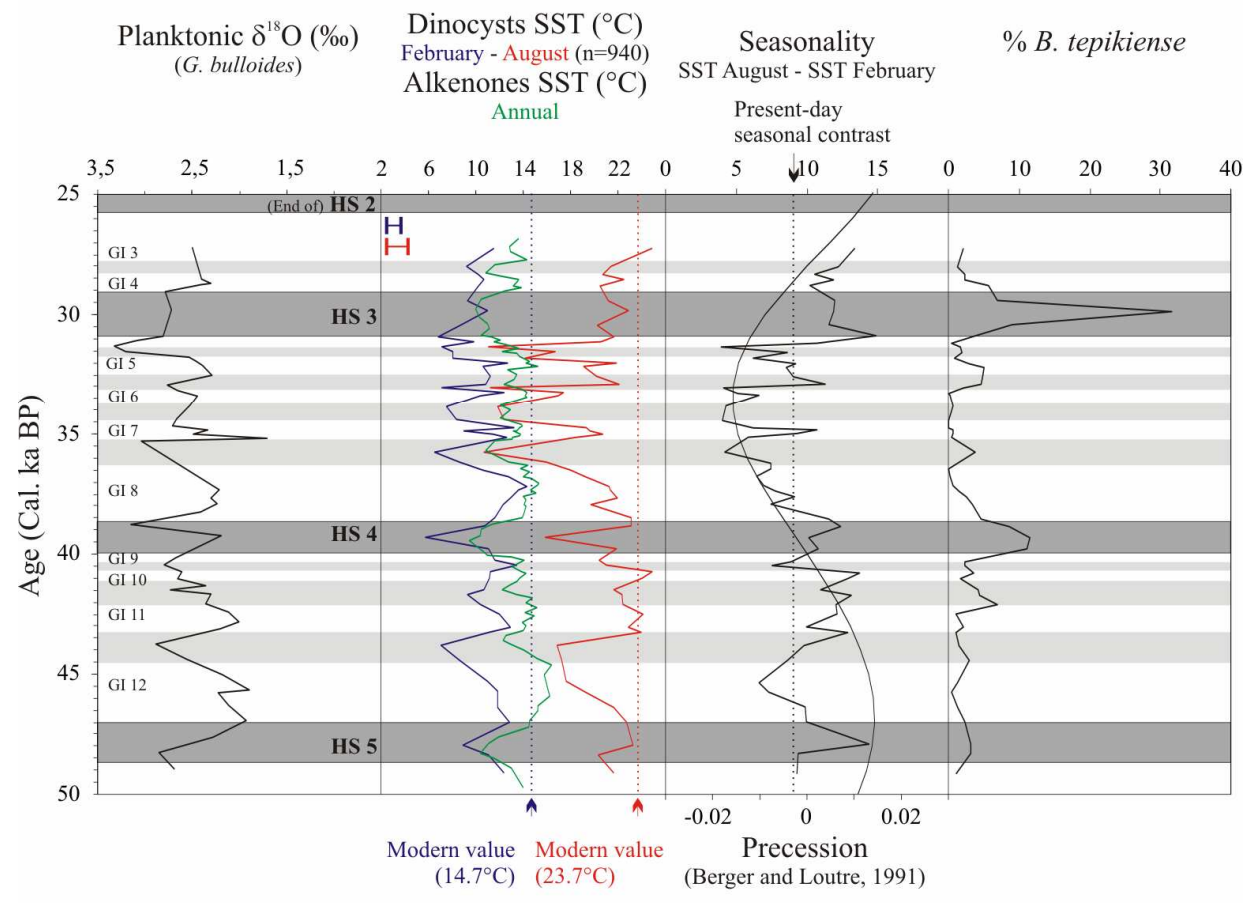

b) MD95-2042 - Iberian Margin

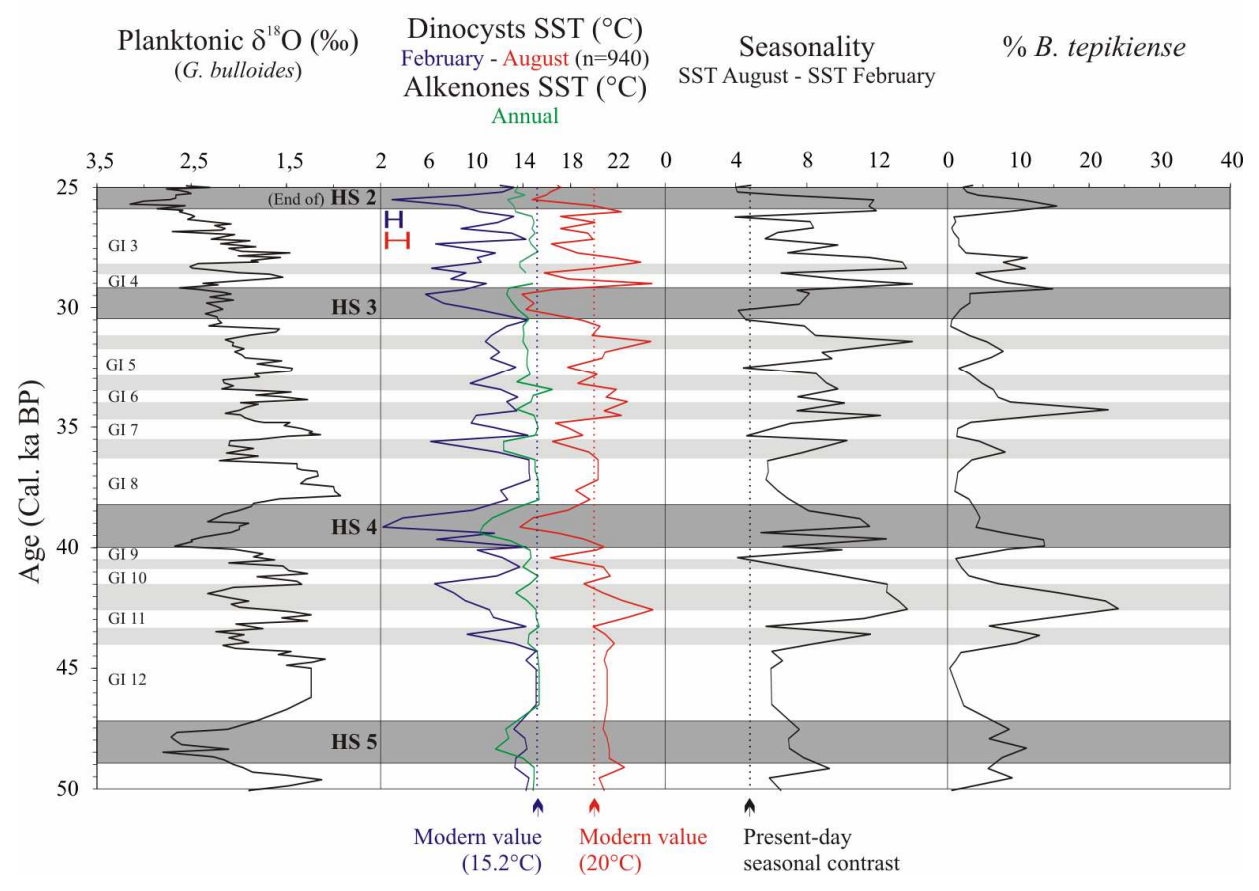

$1580 \quad$ Figure 5 
1581 